\title{
ROMA CAPTA! \\ - UWAGI NA TEMAT RELACJI O ZDOBYCIU RZYMU W 410 I 455 R. W DZIELACH WYBRANYCH AUTORÓW PÓŹNOANTYCZNYCH
}

Zdobycie Rzymu przez Alaryka, króla Wizygotów (ok. 370 - 410/411, król od 395) oraz o prawie pół wieku późniejsze zajęcie i zrabowanie Wiecznego Miasta przez Gejzeryka, króla Wandalów i Alanów († 25 I 477, król od 428) to wydarzenia, które w tradycji historycznej i podręcznikach do nauczania historii zajmują ważne miejsce jako wydarzenia przełomowe i spektakularne. $\mathrm{Na}$ ogół informacje na ten temat są dość ogólnikowe. Działania Alaryka sprowadzane są do trzeciego oblężenia i zajęcia Rzymu w 410 r., pomija się natomiast oblężenie z 408 r., zakończone złożeniem przez Miasto okupu, oraz oblężenie z 409 r., kiedy król Wizygotów nie tylko zajął Rzym i przebywał w nim dłużej niż w 410 r., ale jeszcze wykreował własnego cesarza Priskusa Atallusa († po 416, uzurpator w 409 i 414-415) i sam pełnił przy jego boku funkcję głównodowodzącego wojsk cesarskich w stopniu magistra militum. W znakomitej większości podręczników całkowitym milczeniem pomija się trzecie zdobycie i złupienie Rzymu w 472 r. przez patrycjusza Rycymera († 18 VIII 472), oblegającego w Mieście swego władcę, cesarza Antemiusza (ok. 420 - 11 VII 472, cesarz od 467). Zapewne to ostatnie wydarzenie jako element wojny domowej różni się od dwóch poprzednich grabieży Rzymu dokonanych przez barbarzyńców, choć było chyba najbardziej brzemienne w skutki. Pozostawiając je na boku zajmiemy się $\mathrm{w}$ przedstawionym tekście omówieniem i porównaniem wydarzeń lat 408-410 oraz 455.

Zajęcie Rzymu w 410 i 455 r. relacjonowano w licznych dziełach historycznych. Od razu można odrzucić relacje rocznikarskie, których autorzy ograniczyli się jedynie do podania samej informacji o zdobyciu i złupieniu Miasta oraz mniej lub bardziej ścisłego datowania tego wydarzenia. Interesujące sąjedynie dzieła autorów opisujących szerzej fakty, a czasem także komentujących przebieg wydarzeń. Nie jest też intencją autora tego artykułu przeprowadzanie skrupulatnej analizy źródłoznawczej z ustalaniem wzajemnej zależności

\footnotetext{
* Prof. dr hab. Marek Wilczyński - Kierownik Katedry Historii Starożytnej w Instytucie Historii na Wydziale Humanistycznym Uniwersytetu Pedagogicznego im. Komisji Edukacji Narodowej w Krakowie; e-mail: wilczynski.m@wp.pl.
} 
poszczególnych relacji (choć oczywiście czasem będzie to konieczne), ponieważ tego typu zadanie przekracza ograniczone ramy artykułu i wymagałoby raczej monografii. Celem jest zestawienie i porównanie różnych sposobów opisu i komentowania jednego i drugiego sacco di Roma w relacjach narracyjnych twórców późnoantycznych rzymskiego Zachodu i Wschodu.

1. „Adest Alaricus” 408-410 rok $^{1}$. Św. Augustyn z Hippony (13 XI 354 - 28 VIII 430) pozostawił jako pierwszy bardzo obszerny komentarz i nieco skromniejszą relację dotyczące wydarzeń $410 \mathrm{r}$. Jak wiadomo afrykański Ojciec Kościoła skonfrontował się z oskarżeniami ze strony pogan, widzących przyczynę upadku Imperium w odrzuceniu protekcji starych bogów i oddanie się pod protekcję Chrystusa ${ }^{2}$. Św. Augustyn, polemizując z tymi poglądami zarówno w swym fundamentalnym dziele De civitate Dei, jak i w kazaniach głoszonych w afrykańskich kościołach, głównie koncentruje się na interpretacji wydarzeń, a nie na ich opisie ${ }^{3}$. Wydaje się zreszta, że przynajmniej na poziomie najważniejszych faktów relacje o wydarzeniach w Rzymie w roku 410 były słuchaczom i czytelnikom św. Augustyna wystarczająco dobrze zna-

${ }^{1}$ Problem zdobycia Rzymu w 410 r. budził i budzi ogromne zainteresowanie wśród badaczy i wyliczenie ogromnej ilości publikacji mu poświęconych jest niemożliwe, ale dla zainteresowanych tematem warto podać kilka ważnych najnowszych monografii, w których oblężeniom Rzymu prowadzonym przez Alaryka poświęcono istotne fragmenty: H. Wolfram, Die Goten. Von den Anfängen bis zur Mitte des sechsten Jahrhunderts. Entwurf einer historischen Ethnographie, 3. Aufl., München - Wien 1990, 163-166; M. Wilczyński, Germanie w stużbie zachodniorzymskiej w V w. n.e. Studium historyczno-prosopograficzne, Kraków 2001, 146-161; T. Janßen, Das weströmische Reich vom Tode des Theodosius bis zur Ermordung Stilichos (395-408), Marburg 2004, 240-259; P. Heather, Upadek Cesarstwa Rzymskiego, tłum. J. Szczepański, Poznań 2006, 260-274; G. Kampers, Geschichte der Westgoten, Padeborn - München 2008, 103-104; G. Halsall, Barbarian Migrations and the Roman West, Cambridge 2007, 212-217; A. Demandt, Die Spätantike. Das Römische Reich von Diocletian bis Justinian 284-565 n. Chr., 2. Aufl., München 2008, 112-116; I. Hughes, Stilicho. The Vandal Who Saved Rom, Barnsley 2010, 150-223; M.A. McEvoy, Child Emperor Rule in the Late Roman West AD 367 - 455, Oxford 2013, 177-197; Ch. Delaplace La fin de l'Empire romain d'Occident. Rome et les Wisigoths de 382 à 531, Rennes 2015, 127-150; M. Kulikowski, Wojny Rzymu z Gotami od III wieku do Alaryka, Oświęcim 2015, 135-145.

${ }^{2}$ Obszernie poglądy elit pogańskich na przyczyny i ewentualny sposób zażegnania kryzysu Imperium omówił A. Demandt, Der Fall Roms. Die Auflösung des römischen Reiches im Urteil der Nachwelt, München 1984, 45-55.

${ }^{3}$ Kazimierz Obrycki (Augustyn, Kazanie: O zniszczeniu miasta Rzymu, thum. i oprac. K. Obrycki, WST 12:1999, 159) słusznie zauważa, że św. Augustyn poruszając temat zdobycia Rzymu przez Wizygotów w kazaniach wygłaszanych w Hipponie i Kartaginie w 410 i 411, oraz w De civitate Dei nie skupiał się na opisie wydarzeń, lecz tematem wszystkich tych wystąpień „było, nie samo przedstawienie upadku Rzymu, co raczej moralna i duchowa ocena tych wydarzeń”. Należy założyć, że słuchacze biskupa Hippony posiadali już przed wysłuchaniem jego kazań wiedzę o tym, co stało się w Rzymie, a nawet o związanych z tymi faktami dyskusjach pomiędzy poganami a chrześcijanami. Nie trzeba było więc zapoznawać ich z tym co się stało, ale raczej wythumaczyć, dlaczego Bóg dopuścił do takiego rozwoju wypadków i odeprzeć zarzuty pogan twierdzących, że dawni bogowie nie dopuściliby do tej miary nieszczęścia. 
ne. Augustynowe komentarze nawiązują do trzeciego oblężenia Rzymu z roku 410 , pomijając prawie zupełnie wydarzenia dwóch poprzednich lat ${ }^{4}$. Szczególnie ignorowanie drugiego oblężenia może dziwić, ponieważ Alaryk po wykreowaniu uzurpacji Atallusa żywił poważne zamiary zajęcia Afryki w imieniu wspieranego przez siebie imperatora, co stanowiło poważne zagrożenie dla biskupa Hippony i jego wiernych. Gdyby planowany desant wizygocki pod wodzą zaufanego Alarykowego wodza Drumasa (IV/V w.) doszedł do skutku to możliwe, że św. Augustyn o 20 lat wcześniej zmierzyć by się musiał z grozą barbarzyńskiego oblężenia.

Bezpośrednim, pisanym na gorąco i zarazem obszernym komentarzem jest De excidio urbis Romae ${ }^{5}$. Św. Augustyn potwierdza, że Miasto zostało zajęte i ograbione, a jego mieszkańcy byli narażeni na cierpienia, poniżenia, a nawet śmierć, jednak jego zdaniem wszystkie te wydarzenia w porównaniu z nieszczęściami znanymi z historii rzymskiej lub z Biblii nie są niczym szczególnym. Nie można z pełnym spokojem stwierdzić, że nic się nie stało, ale w porównaniu do innych plag, które w przeszłości dotykały ludzkość wcale nie są to wydarzenia tragiczne. Co więcej, Bóg potraktował Rzym stosunkowo łagodnie. Poganie drwili, nawiązując do opowieści o Sodomie i Gomorze i pytali, czy w Rzymie brakło pięćdziesięciu sprawiedliwych, z uwagi na których Pan mógł powstrzymać nieszczęście. Św. Augustyn przypomina jednak, że Sodoma została zrównana z ziemią bezpowrotnie, a w Rzymie ocalało bardzo wielu, którzy w dodatku po odejściu Gotów powrócili do swych domostw, czego o żadnym mieszkańcu Sodomy powiedzieć nie można. Ci zaś, którzy schronili się w rzymskich kościołach, żadnej szkody nie ponieśli ${ }^{6}$. Dalej zapytuje, czy niedole mieszkańców Miasta w jakimkolwiek stopniu porównać można do strasznych cierpień Hioba? ${ }^{7}$ Bóg okazał Rzymianom miłosierdzie ocalając wielu, mimo licznych grzechów mieszkańców starej stolicy, a tym bardziej łaskawy był dla ludu Konstantynopola, który w czasach cesarza Arkadiusza (ok. 377 - 1 V 408, cesarz od 19 I 383) za sprawą przekonywujących kaznodziejów w porę odrzucił grzechy i pokutował, dzięki czemu miasto nie poniosło strat, a barbarzyńcy od niego odeszli ${ }^{8}$. Rzym został przez Boga surowiej skarcony,

${ }^{4}$ Listy do Italiki (Augustinus, Epistula 99, PL 33, 364-365) i Wiktoryna (Augustinus, Epistula 111, PL 33, 422-427) zawierają krótkie nawiązania do pierwszego oblężenia w 408 r. W drugim z listów św. Augustyn szerzej porusza problem nieszczęść i zła, jakie w związku z najazdem barbarzyńców trapi ziemie Italii, Galii i Hiszpanii. Nie zapomina przy tym jednak wspomnieć, że także w odległej od tych miejsc Hipponie nie panuje spokój, bowiem choć nie sięgają po nią barbarzyńcy, to jednak stale zagraża jej kler donatystyczny i zbrodnie circumcelliones (Augustinus, Epistula 111, 1, PL 33, 422). Jak widać nie tylko jego wierni, ale czasami i on sam skupiał się na lokalnych, a nie imperialnych problemach.

${ }^{5}$ Por. Augustinus, De excidio urbis Romae (De Urbis excidio sermo), PL 40, 715-723.

${ }^{6}$ Por. tamże II 2, PL 40, 717-718; V 5, PL 40, 720-721.

${ }^{7}$ Por. tamże III 3, PL 40, 718-719.

${ }^{8}$ K. Obrycki (Augustyn, Kazanie: O zniszczeniu miasta Rzymu, s. 168, nota 41) sądzi, że chodzi tu o wydarzenia z 395 r., kiedy pod murami Konstantynopola Alaryk rokował z Rufinem, a stąd 
ale wielu mieszkańców zbiegło, licznych oszczędzono, a kościoły były miejscem ocalenia ${ }^{9}$. W De civitate Dei nawiązania do zajęcia Rzymu występują w wielu miejscach. Po wskazaniu absurdalności oskarżeń pogan ${ }^{10}$ św. Augustyn przypomina, że w czasach pogaństwa spadały na Rzym liczne klęski, mimo rzekomej opieki bóstw ${ }^{11}$. Nieporównanie więcej senatorów rzymskich padło od proskrypcji sullańskich ${ }^{12}$ niż od miecza Gotów w roku 410. Dopiero nadejście chrześcijaństwa i szczęśliwe rządy cesarzy Konstantyna Wielkiego (27 II 272 - 22 V 337, cesarz od 25 VII 306) i Teodozjusza Wielkiego (11 I 346 - 17 I 395, cesarz od 19 I 379) przyniosły ulgę w cierpieniach i choć nie uwolniły od klęsk (vide Rzym w 410 r.), to jednak skutki ich zdecydowanie złagodziły. Wyrazem szczególnej łaski Bożej i wielkim zwycięstwem Rzymian było pokonanie Radagaisa ( $† 23$ VIII 406) ${ }^{13}$, dzikiego poganina, który nie oszczędziłby nikogo, podczas gdy chrześcijanin Alaryk pozwolił ocaleć tak wielu. Św. Augustyn nie bagatelizuje zdobycia Rzymu w 410 r., ale wykazuje jasno, że wydarzenie to było częścią Bożego planu, przy czym Stwórca obszedł się z Rzymianami stosunkowo łagodnie.

$\mathrm{Na}$ gruncie historycznym komentarze św. Augustyna rozwinął Paweł Orozjusz (383 - 418/423?). Przyjmuje się, że Orozjusz otrzymał od Augustyna zadanie, by w swoim dziele historycznym ukazać słuszność tez wyrażonych w De civitate Dei z perspektywy historycznej i wskazać, że nieszczęścia podobne wydarzeniom 410 r. zdarzały się wcześniej i nie tylko były podobne, ale nawet dużo straszniejsze i godne pożałowania, tym bardziej im dalsze były od czasów chrześcijańskich. Tempora christiana miały przynieść ludzkości znaczne złagodzenie cierpień. Logika historii wykłada się też w liczbach: np. 10 plag egipskich porównywane jest z 10 prześladowaniami chrześcijan. Podobnie jak Babilon padł po 1164 latach istnienia, tak i Rzym został złupiony przez Alaryka w 1164 lata ab Urbe condita. Pokojowe panowanie Augusta wiąże się z zapoczątkowaniem czasu chrześcijańskiego (tempora christiana)

ruszyli na Trację, Macedonię i Grecję, i dopiero interwencja Stilichona (360 lub 365 - 22 lub 23 VIII 408) ocaliła Konstantynopol. Uważam, że można to interpretować inaczej, tym bardziej, że o Stilichonie w latach 395-398 da się powiedzieć wiele, ale nie to, że ocalił Konstantynopol. Sam św. Augustyn pisze tak ogólnie, że nie można jednoznacznie ustalić o jakie wydarzenia mu chodzi. Jednak zarówno upomnienia kaznodziei, jak i wzmianka o ogniu w mieście i zamiarze opuszczenia go, a potem o cudownym ocaleniu może pasować też do wydarzeń z lat 400-401, czyli do rewolty Gainasa.

${ }^{9}$ Por. Augustinus, De excidio urbis Romae VII 8, PL 40, 722-723.

${ }^{10}$ Por. tenże, De civitate Dei I 29, rec. E. Hoffmann, CSEL 40/1, Pragae - Vindobonae - Lipsiae $1899,51,23-52,2$.

${ }^{11}$ Por. tamże II 3, CSEL 40/1, 62, 18 - 63, 1; III 17-27, CSEL 40/1, 135, 20 - 154, 24.

${ }^{12}$ Por. tamże III 28, CSEL 40/1, 155, 23-28.

$13 \mathrm{Na}$ temat przebiegu i znaczeniu najazdu Radagaisa por. J.W.P. Wijnendaele, Stilicho, Radagaissus, and the So-Called „Battie of Faesulae” (406 CE), „Journal of Late Antiquity” 9 (2016) nr 1, 267-284. Por. też Janßen, Das weströmische Reich vom Tode des Theodosius bis zur Ermordung Stilichos, s. 187-201 i 260-274; Hughes, Stilicho. The Vandal Who Saved Rom, s. 150-167; Wilczyński, Germanie w stużbie zachodniorzymskiej w V w. n.e., s. 367-370. 
i od Augusta świat przygotowywany jest do pełnej chrystianizacji. Imperium Romanum, które staje się przestrzenią rozwoju chrześcijańskiego dzieła zbawienia $^{14}$, tworzy ramy, w których ma nastąpić spełnienie czasu chrześcijańskiego, czyli paruzja i nadejście Królestwa Bożego. Podobnie jak św. Augustyn opisując czasy przedchrześcijańskie ukazuje Orozjusz całą gamę nieszczęść, a od czasu panowania Augusta dostrzega postępującą poprawę. Jak zatem wythumaczyć wydarzenia roku 410? Jak najbardziej optymistycznie: Alaryk i jego Goci postrzegani są jako karzące narzędzie Opatrzności, które niesie zbawienną karę i napomnienie. W tym kontekście należy zastanowić się nad tym, w jakim znaczeniu Orozjusz użył zwrotu adest Alaricus, którym rozpoczyna opis wydarzeń $410 \mathrm{roku}^{15}$. Adsum oznacza zarówno jestem tu, jak i spieszę z pomoca, niose pomoc, stoję po twojej stronie, zatem być może przybycia króla Gotów nie należy traktować jako plagę, lecz jako formę realizacji Boskiego planu zbawienia. Podobnie jak św. Augustyn, także Orozjusz buduje dla potrzeb swej argumentacji dychotomiczny obraz barbarzyńców, trapiących z woli Boga Imperium. Chrześcijański, choć ariański Alaryk (Christianus propiorque Romano) jest zdecydowanie postacią pozytywną i zasadniczo kontrastową w stosunku do dzikiego i pogańskiego Radagaisa (paganus, barbarus et uere Scytha), który wszak ślubował swoim bożkom krew wszystkich Rzymian w ofierze ${ }^{16}$, zaś pobożny Alaryk i jego ludzie mordowali z umiarem i uszanowali azyl kościelny.

Orozjusz nie zaprzecza, że w czasie trzydniowej obecności Gotów w Mieście dochodziło do morderstw, podpaleń, rabunku i gwałtów, jednak podobnie jak św. Augustyn dowodzi, że w porównaniu z pożarem spowodowanym przez Nerona (15 XII 37 - 9 IV 68, cesarz od 13 X 54), czy prawie rocznym pobytem Gallów w Rzymie w 387 r., tak czas jak i opłakane skutki działań barbarzyńców były w 410 r. nieporównanie mniejsze ${ }^{17}$. Alaryk działał nawet łagodniej niż chciał tego sam Bóg i nie do końca wymierzył sprawiedliwą karę, czego dowodem był fakt, że domy, których Goci nie zburzyli, zniszczyły wkrótce po ich odejściu pioruny niebieskie ${ }^{18}$.

Niewątpliwie centralną sceną Orozjuszowego opisu jest opowieść o mniszce, która pytana przez jednego z wizygockich wojów o ukryte skarby zdradza mu miejsce ukrycia świętych naczyń i precjozów należących do kościoła św. Piotra. Zdjęty lękiem Bożym Got powiadamia o swoim odkryciu Alaryka,

\footnotetext{
${ }^{14}$ Nie jest to odosobniony pogląd. U początku V w. chrześcijański poeta Prudencjusz nie tylko w swoich utworach bronił chrześcijaństwa przed zarzutami pogan, ale ukazywał chrześcijaństwo jako nową formę tożsamości dzieci dawnych Kwirytów i wykazywał logiczny, nierozerwalny i korzystny dla Rzymian związek między rzymskością a chrześcijaństwem, por. Demandt, Der Fall Roms, s. 66: „Romanitas und Christianitas sind nirgends so eng verbunden wie bei Prudentius”.

${ }^{15}$ Por. Orosius, Historiae adversvm paganos VII 39, 1, rec. C. Zangemeister, CSEL 5, Vindobonae $1882,544,15$.

${ }^{16}$ Por. tamże VII 37, 9-10, CSEL 5, 539, 11-13.

${ }^{17}$ Por. tamże VII 39, 16-17, CSEL 5, 548, 3-9.

${ }^{18}$ Por tamże VII 39, 18, CSEL 5, 548, 9-13.
} 
a ten nakazuje przenieść bezcenne skarby z szacunkiem do kościoła św. Piotra, pod ochroną (cum defensione) wojowników królewskich. Precjoza niesione są uroczyście przez Rzymian, którym towarzyszą dla ochrony Goci z dobytymi mieczami ${ }^{19}$. Concurrunt undique ad uasa Petri uasa Christi, czyli kryjacy się dotąd przed barbarzyńcami mieszkańcy Rzymu. Nawet poganie szukają schronienia w rozmodlonym i bezpiecznym tłumie. Rzymianie i Goci wspólnie wznoszą ku Bogu pobożne hymny. Za sprawą Boga sytuacja zmienia się diametralnie. Zamiast uciekać przed wściekłością barbarzyńców Romani confugientes bez lęku kroczą ulicami miasta, a ochraniają ich dzielący religijny zapał Rzymian barbari defensores ${ }^{20}$. Scena mistycznego pojednania napastników i ofiar zapowiada przyszłe pojednanie rzeczywiste. Orozjusz traktuje wprawdzie Gotów jak barbarzyńców, ale przyznaje, że łączy ich z Rzymianami wiara niczym dzieci w jednym domu Bożym, co pozwala żywić nadzieję, że barbarzyńscy najeźdźcy Alaryka jako chrześcijanie ulegną integracji z ludnością Imperium Romanum, poznając dobro płynące $\mathrm{z}$ prawdziwej religii ${ }^{21}$. Jako bezpośrednio związane z najazdem Alaryka, Orozjusz wskazuje rzekome knowania Stilichona, chcącego jakoby wynieść na tron cesarski swego syna Eucheriusza (389-408) i, zdaniem autora, ponoszącego winę za sprowokowanie najazdu barbarzyńców na Galię w końcu 406 r. Nie oskarża wprawdzie Stilichona o bezpośrednie sprowokowanie Alaryka do oblężeń Rzymu, ale widzi związek pomiędzy jednym a drugim, początkując eskalację coraz ostrzejszych oskarżeń pod adresem Stilichona i jego bliskich ${ }^{22}$.

W szerszych łacińskich opisach późniejszego okresu o winie Stilichona, który miał sprowokować gocki atak na Rzym, mówił Jordanes (VI w.) Opowiada on, że zaraz po elekcji królewskiej (395) Alaryk wkroczył do Italii jakby „ogołoconej z mężów”23 i nie napotykając oporu dotarł do Rawenny ${ }^{24}$.

${ }^{19}$ Por. tamże VII 39, 3-9, CSEL 5, 545, 10 - 546, 14.

${ }^{20}$ Por. tamże VII 39, 10, CSEL 5, 546, 14 - 547, 1: ,concurrunt undique ad uasa Petri uasa Christi, plurimi etiam pagani Christianis professione etsi non fide admiscentur et per hoc tamen ad tempus, quo magis confundantur, euadunt; quanto copiosius adgregantur Romani confugientes, tanto auidius circumfunduntur barbari defensores". Samo użycie ostatnich dwóch słów cytatu w kontekście znanych nam wydarzeń wydaje się być postawieniem relacji historycznej na głowie. Jednak Orozjusz wyraźnie ukazuje pozytywny obraz Alaryka, chroniącego to, co święte, mimo że jako narzędzie Boskiej próby i kary sroży się w plądrowanym Mieście.

${ }^{21}$ Por. tamże VII 41, CSEL 5, s. 554, 7-14: „Quamquam si ob hoc solum barbari Romanis finibus inmissi forent, quod uulgo per Orientem et Occidentem ecclesiae Christi Hunis Suebis Vandalis et Burgundionibus diuersisque innumeris credentium populis replentur, laudanda et adtollenda misericordia Dei uideretur, quandoquidem, etsi cum labefactione nostri, tantae gentes agnitionem ueritatis acciperent, quam inuenire utique nisi hac occasione non possent".

${ }^{22}$ Por. tamże VII 38, 1-6, CSEL 5, 542, 16 - 544, 12.

23 Jordanes, De origine actibusque Getarum 147, ed. Th. Mommsen, MGH Auctores Antiquissimi V/1, Berolini 1882, 96, 19, thum. E. Zwolski: Kasjodor i Jordanes. Historia gocka czyli scytyjska Europa, Rozprawy Wydziału Historyczno-Teologicznego 49, Lublin 1984, 116.

${ }^{24}$ Por. tamże, MGH Auctores Antiquissimi V/1, 96, 19-20. 
Poprosił cesarza Honoriusza (9 IX 384 - 15 VIII 423, cesarz od 17 I 395) o nadanie ziem ${ }^{25}$, a ten gotów był przekazać mu tereny Galii i Hiszpanii, czyli „kraje, które niemal już utracił i po których rozpuszczał niszczycielskie zagony Gejzeryk, król Wandalów"26. W drodze do Galii pod Pollentią Gotów zaatakował zdradziecko Stilichon, jednak oni, jak zwykle mężni, zwyciężyli i wojsko Stilichona wycięli niemal w całości, po czym rozgniewani zawrócili ku Rzymowi, plądrując wszystko po drodze. Miasto zajęli, ale na rozkaz Alaryka nie podpalali ani nie mordowali, a jedynie grabili, szanując jednocześnie świątynie chrześcijańskie ${ }^{27}$. Alaryk ze zdobytymi łupami ruszył do krainy Bruttiów, by przeprawić się do Afryki, ale burza morska zniweczyła te plany, a Alaryk wkrótce potem niespodzianie zmarł ${ }^{28}$. Bardzo krótki w porównaniu z relacją Orozjusza opis wydarzeń zachowuje jednak podstawowe przesłanie - doszło do zdobycia i oblężenie Miasta, jednak poza złupieniem Rzymu Goci nie wyrządzili Rzymianom szkód i szanowali w pełni azyl kościelny. W drugim ze swoich dzieł, w historii dziejów rzymskich Jordanes krótko informuje o zajęciu Rzymu i dodaje informację o wzięciu do niewoli i uprowadzeniu z Miasta Galli Placydii (ok. 390 - 27 XI 450) przyrodniej siostry cesarza Honoriusza, krótko informując też, że później została ona żoną króla Ataulfa († 415, król od 410/411) ${ }^{29}$.

Relacje Orozjusza i Jordanesa zostały też wykorzystane i skompilowane w stosunkowo późnym dziele historycznym Pawła Diakona (720/730 - 13 IV(?)/na pewno przed 800). Równie surowo jak Orozjusz ocenia on Radagaisa, którego najazd opisuje, wiernie przepisując swego poprzednika z począt$\mathrm{ku} \mathrm{V}$ wieku ${ }^{30}$. Natomiast relacja dotycząca wydarzeń roku 410 jest kompilacją przekazów Orozjusza i Jordanesa. Kolejność wydarzeń pokrywa się z chronologicznie nieprawdziwym opisem Jordanesa, jedynie zaostrza się ocena Stilichona. Paweł pisze wprost, że dążąc do zagłady państwa, Stilichon sprowoko-

${ }^{25}$ Por. tamże 152, MGH Auctores Antiquissimi V/1, 97, 16-20.

${ }^{26}$ Tamże 153, MGH Auctores Antiquissimi V/1, 98, 1-3, thum. Zwolski, s. 117.

${ }^{27}$ Por. tamże 154-156, MGH Auctores Antiquissimi V/1, 98, 5 - 99, 1. Relacja ta przedstawia zupełnie fałszywy obraz wydarzeń związanych z wojną ,pollentyńską”. W trzech kolejnych akapitach Jordanes miesza fakty chronologicznie poprzedzające oblężenia Rzymu. Pomysł skierowania Alaryka do Galii przeciw uzurpatorowi Konstantynowi III († przed 18 IX 411, cesarz od 407) pojawił się dopiero w 408 r., a w narracji występuje przed wojną Polentyńską (401-402), w której istotnie Stilichon zaatakował Gotów, ale nie ciagnnących do Galii i Hiszpanii, tylko oblegających Mediolan. Kolejne lata Alaryk spędził w Macedonii i w Emonie (Ljublianie), a dopiero w roku 408 ponownie pojawił się w Italii.

${ }^{28}$ Por. tamże 156-157, MGH Auctores Antiquissimi V/1, 99, 1-10.

${ }^{29}$ Por. tenże, De summa temporum vel origine actibusque gentis Romanorum 323, ed. Th. Mommsen, MGH Auctores Antiquissimi V/1, Berolini 1882, 41, 29-31: „Halaricus rex Vesegotharum vastatam Italiam Romam ingressus est opesque Honorii Augusti depraedatas Placidiam sororem eius duxit captivam, quam post haec Atauulfo successori suo, in matrimonio ut acciperet, delegavit".

${ }^{30}$ Paulus Diaconus, Historia Romana XII 12, rec. H. Droysen: Eutropi breviarium ab urbe condita cum versionibus graecis et Pauli Landolfique additamentis, MGH Auctores Antiquissimi II, Berolini 1879, 193, 8-23. 
wał Gotów (Stilicho comes in perniciem rei publicae Gothos pertemptans) ${ }^{31}$ do ataku na Rzym. Dokładnie też powtarza w dalszych rozdziałach oskarżenia Orozjusza dotyczące rzekomego spisku Stilichona, który, „chcąc przyoblec w purpurę jednego chłopca, przelewał krew całego rodzaju ludzkiego" ${ }^{32}$. Myli jednak chronologię informując, że inwazja barbarzyńców na Galię, będąca rzekomo częścią „,spisku” Stilichona miała nastąpić dopiero dwa lata po wydarzeniach związanych z zajęciem Miasta przez Alaryka. Wtedy też nastapić miał bunt wojsk, które kierowane słusznym gniewem zamordowały Stilicho$\mathrm{na}^{33}$. Pojawia się też informacja, że Rzym padł po 1164 latach istnienia, jednak brak odwołania do Babilonu, występującego u Orozjusza i św. Augustyna. Powtarza też za Orozjuszem informację o piorunach, które spaliły część ocalałych domostw w Mieście, dopełniając wyroki Boże ${ }^{34}$.

Inaczej w relacjach o wydarzeniach lat 408-410 rozkładają akcenty autorzy wschodniorzymscy, piszący po grecku. Rzeczowe i zwięzłe informacje o zajęciu Rzymu przez Alaryka spisał anomejski historyk Kościoła Filostorgiusz (368 - ok. 429). Krótko informuje on, że barbarzyńskie oddziały w służbie cesarskiej po śmierci Stilichona próbowały ocalić Eucheriusza, jednak gdy to się nie udało przeszły na stronę Alaryka. To właśnie oni, pragnąc zemsty, pchnęli wodza Gotów przeciw Rzymowi ${ }^{35}$. Wspomina o blokadzie dostaw żywności i głodzie szalejącym w Mieście, jak też o uzurpacji Atallusa ${ }^{36}$. Ta ostatnia miała się zakończyć, gdy Sarus, który zdaniem Filostorgiusza przejął po Stilichonie naczelne dowództwo, zadał Alarykowi klęskę tak znaczną, że ten chciał rokować z Honoriuszem o pokój, jednak Sarus miał przekonać Honoriusza do odrzucenia tych propozycji. Rozwścieczony Alaryk pociągnął więc po raz trzeci na Rzym. Miasto dotknęły mordy, ogień i niewola narzucona przez barbarzyńców ${ }^{37}$. Filostorgiusz nie pisze o próbach czy karach zesłanych przez Boga, zamiast tego dość trafnie analizuje rzeczywiste wydarzenia polityczne.

Sokrates Scholastyk (ok. 380 - ok. 450) z kolei twierdził, że Alaryk, który za swe zasługi w bitwie nad rzeką Frigidus w 394 r. otrzymał wysoki rzymski

${ }^{31}$ Tamże XII 13, MGH Auctores Antiquissimi II, s. 194, 1.

32 Tamże XII 16, MGH Auctores Antiquissimi II, s. 195, 18-19, thum. I. Lewandowski: Paweł Diakon, Historia rzymska, Warszawa 1995, 111.

${ }^{33}$ Por. tamże XII 16, MGH Auctores Antiquissimi II, s. 195, 16-18.

${ }^{34}$ Por. tamże XII 16, MGH Auctores Antiquissimi II, s. 195, $20-21$.

${ }^{35}$ Por. Philostorgius, HE XII 3, ed. J. Bidez - F. Winkelmann, GCS 21, Berlin 1972, 141, 13-19.

${ }^{36}$ Por. tamże XII 4-5, GCS 21, 143, 1 - 144, 15.

${ }^{37}$ Por. tamże XII 3, GCS 21, 142, 11-25. W tej opowieści błędy sąsiadują z prawdziwymi faktami. Alaryk zdecydował o pozbawieniu Atallusa swego wsparcia i podjęciu rozmów z Honoriuszem po nieudanej próbie przejęcia Aryki rzymskiej, przymuszony niedostatkami aprowizacyjnymi. Sarus nie został magistrem militum w miejsce Stilichona, ale jako comes w służbie Honoriusza istotnie rozbił w Pinecie spory oddział dowodzony przez szwagra Alaryka, Ataulfa. Ponieważ stało się to w toku rozmów pokojowych, a cesarz odmówił żądaniu Alaryka, by ukarać Sarusa, król Gotów zerwał rokowania i po raz trzeci i ostatni obległ Rzym w 410 r. O przebiegu wypadków: Wilczyński, Germanie w stużbie zachodniorzymskiej w V w. n.e., s. 158-159. 
stopień wojskowy zdecydował się szukać władzy i sławy na Zachodzie ${ }^{38}$. Jego wyprawa na Illyricum nie udała się, ponieważ zatrzymali go Tesalo$w^{39}{ }^{39}$. O prawdziwej przyczynie powstrzymania plądrowania Illyricum w latach 396-398, czyli o dwóch wyprawach Stilichona do Grecji przeciw Alarykowi, Sokrates milczy, podobnie jak o wojnie „pollentyńskiej” i wszystkich innych działaniach Stilichona. Nie informuje też o żadnym z ważnych wydarzeń politycznych czy militarnych, które miały miejsce na Zachodzie w okresie poprzedzającym zdobycie Rzymu. Samo zaś to wydarzenie relacjonuje mieszając $\mathrm{w}$ jedno fakty dotyczące drugiego i trzeciego oblężenia. Nie minimalizuje strat, lecz pisze o spustoszeniu miasta, spaleniu wielu budowli i mordowaniu senatorów, przeciwko którym ferowano różne wyroki $(\text { sic! })^{40}$. Nawiązując do wydarzeń 409 r. pisze, że Alaryk ,naigrawając się z władzy cesarskiej" powołał na tron uzurpatora Atallusa, którego jednego dnia traktował jak władcę, a $z$ kolei innego dnia jak sługę ${ }^{41}$. Dopiero wieść o wysłaniu przez cesarza wschodniorzymskiego Teodozjusza II (10 IV 401 - 28 VII 450, cesarz od 1 V 408) potężnej floty na odsiecz Rzymowi spowodowała paniczną ucieczkę Alaryka z Rzymu, skąd wywiózł również liczne łupy $^{42}$. Sokrates wskazuje też jednoznacznie na nadprzyrodzony, kategoryczny imperatyw, który popchnął Alaryka do zniszczenia Rzymu. Czyni to $\mathrm{w}$ formie anegdoty o pobożnym mnichu usiłującym zatrzymać ciągnącego na Rzym barbarzyńcę. Król Gotów miał mu wówczas odpowiedzieć „Nie idę ja [...] z własnej chęci do tego, co tam mnie czeka, lecz każdego dnia niepokoi mnie ktoś i kusi mówiąc: «Idź, pójdź zburzyć miasto Rzymian»"43. Można tę opowieść potraktować jako inną formę wyrażenia wywodzącego się od św. Augustyna i powszechnego na Zachodzie przekonania, że Alarykowe sacco di Roma było formą próby lub kary zesłanej od Boga ${ }^{44}$.

Tą samą anegdotę o nieznanym mnichu opowiedział korzystający z dzieła Sokratesa Hermiasz Sozomenos (ok. 400-450). Jednak w innych punktach

${ }^{38}$ Por. Socrates, HE VII 10, 1, ed. G.Ch. Hansen, GCS NF 1, Berlin 1995, 355, 10-12.

${ }^{39}$ Por. tamże VII 10, 2-3, GCS NF 1, 355, 14-18.

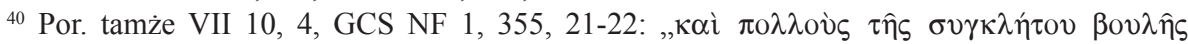

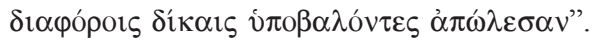

${ }^{41}$ Por. tamże VII 10, 5, GCS NF 1, 355, 22-25, thum. S.J. Kazikowski: Sokrates Scholastyk, Historia Kościoła, Warszawa 1972, 449.

${ }^{42}$ Por. tamże VII 10, 6-7, GCS NF 1, 355, 25-29. Rzeczywistym powodem opuszczenia Rzymu po zaledwie trzech dniach były zapewne drastyczne braki w aprowizacji. Miasto przymierało głodem, a Gotom nie wiodło się wiele lepiej. Pozostanie na dłużej w murach Rzymu tylko by tę sytuację pogorszyło.

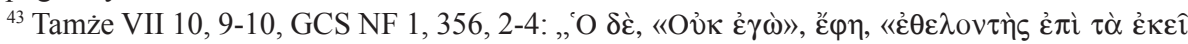

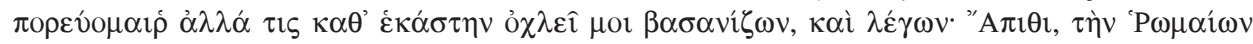

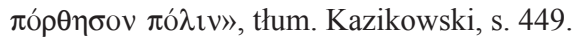

${ }^{44}$ Mischa Meier i Steffen Patzold (August 410 - ein Kampf um Rom, Stuttgart 2010, 86-87) sugerują, że Sokrates sympatyzujący z nowacjanami, mógł najazd Alaryka uważać za karę Bożą za antynowacjańskie działania papieża Innocentego I († 12 III 417, papież od 21 XII 401). W takim przypadku głos nieustannie nękający Alaryka byłby bezpośrednim wezwaniem Bożym. 
relacji przyjął własną narrację. Przede wszystkim skorzystał z okazji, by zaznaczyć głęboki kontrast pomiędzy targanym ciągłymi plagami Zachodem, a szczęśliwym Wschodem, którego władca zapewnił poddanym spokój i obronę, choć był tylko dziecięciem ${ }^{45}$. Dalej Sozomen umieszcza informacje o wydarzeniach związanych z wszystkimi trzema oblężeniami Rzymu. Informuje, że Alaryk po śmierci Stilichona w 408 r. obległ Miasto i odciął dostawy żywności ${ }^{46}$. Następstwem głodu było zbiegostwo niewolników. Rzymianie pogorszyli swoje położenie obrażając Boga wezwaniem pogańskich haruspików, którzy, jak powiadano, wywołując grzmoty i pioruny odegnali Gotów spod miasta Narniae ${ }^{47}$. Sozomenos podkreśla zaangażowanie się papieża Innocentego I w mediacje pomiędzy Alarykiem a Honoriuszem ${ }^{48}$. Po omówieniu oblężenia 409 r. i uzurpacji Atallusa, któremu Sozomenos nie zapomniał wytknąć wyznawania religii pogańskiej i przyjęcia chrztu od gockiego ariańskiego biskupa Sigesara ${ }^{49}$, następuje opis zajęcia Rzymu zdradą w 410 r., poprzedzonego ponownie próbą rokowań, storpedowanych skutkiem rad Sarusa, przeciwnego rokowaniom z Alarykiem ${ }^{50}$ Autor podkreśla poszanowanie azylu kościelnego ${ }^{51}$ i stwierdza, że ocaliło to sporą liczbę mieszkańców, którzy potem zasiedlili Miasto na nowo ${ }^{52}$. Dalej opowiada, podobnie jak Orozjusz, o pobożnej Rzymiance, która co prawda nie przechowywała świętych precjozów, ale tak skutecznie opierała się żądzy pewnego gockiego wojownika,

${ }^{45}$ Por. Sozomenus, HE IX 6, 1, ed. J. Bidez - G.Ch. Hansen, GCS NF 4, 397, 19-20: „Tф̀ $\mu \grave{\varepsilon} v$

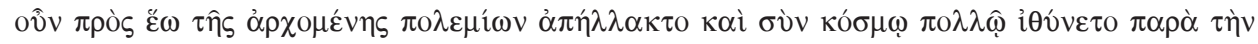

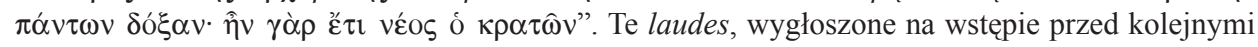
jedenastoma rozdziałami, poświęconymi nieszczęściom trapiącym Zachód od najazdu Alaryka aż do zgonu Honoriusza, mają jednoznacznie wykazać wyższość i stabilność Wschodu pod rządami Teodozjusza II. Podobnemu celowi służyć miała Sokratesowa opowieść o panice, jaką rzekomo napełniła Alaryka wieść o wyruszeniu przeciw niemu wielkiej floty, wysłanej z Konstantynopola na odsiecz Rzymowi.

${ }^{46}$ Por. tamże IX 6, 2, GCS NF 4, 397, 21-26. Autor twierdzi, że Alaryk próbował dojść do porozumienia z cesarzem Honoriuszem, ale wobec odmowy ze strony cesarskiej rozpoczął pierwsze oblężenie Miasta.

${ }^{47}$ Por. tamże X 6, 3-4, GCS NF 4, 397, 26 - 398, 6.

${ }^{48}$ Por. tamże IX 7, 1, GCS NF 4, 398, 18-19.

${ }^{49}$ Por. tamże IX 8, 1-11, GCS NF 4, 399, 9 - 401, 4; IX 9, 1, GCS NF 4, 401, 5-12. W drugim z cytowanych fragmentów autor wspomina o nadziei pogan na przywrócenie dawnego kultu i zwrot świątyń oraz o radości arian, którzy sadzili, że ich nowy brat w wierze, cesarz Atallus, sprawi, że jak za cesarzy Konstancjusza II (7 VIII 317 - 3 IX 361, cesarz od 9 IX 337) i Walensa (ok. 328 - 9 VIII 378, cesarz od 23 III 364) będą mogli przejmować kościoły zwolenników nicejskiej ortodoksji. $\mathrm{Na}$ temat stosunku tych cesarzy do arianizmu por. D. Spychała, Cesarze rzymscy a arianizm od Konstantyna Wielkiego do Teodozjusza Wielkiego (312-395), Poznań 2007, 52-57, 96-114, 123-126, 170-184 i 188-193.

${ }^{50}$ Por. Sozomenus, HE IX 9, 2-4, GCS NF 4, 401, 13-23.

${ }^{51}$ Por. tamże IX 9, 4, GCS NF 4, 401, 23-25.

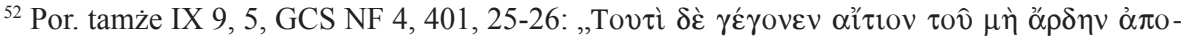

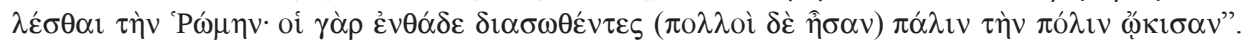


że ten zbudowany jej postawą osobiście odprowadził ją do kościoła św. Piotra i nawet dał strażnikom strzegącym świątyni sześć denarów na utrzymanie niewiasty ${ }^{53}$. Pobożny Alaryk i jego szlachetny wojownik ocieplają wizerunek Gotów i przeciwstawieni są głupiej bezbożności Rzymian, szukających ocalenia w dawnych pogańskich obrzędach. Zarówno Sokrates jak i Sozomenos ignorują okoliczności polityczne związane z upadkiem Stilichona (nie imputują też straconemu magistrowi militum chęci zdrady czy uzurpacji), a głównej przyczyny nieszczęść dopatrują się w niedostatecznej pobożności mieszkańców Miasta.

W pełni zgadza się z nimi Zosimos (2. poł. V w.), historyk o poglądach propogańskich, choć oczywiście niedostateczną pobożność, czy też bezbożność rozumie zupełnie inaczej. I on wspomina o haruspikach z Etrurii, którzy pod Narniae przegnali Gotów, korzystając z potężnych i świętych obrzędów. Bezbożni chrześcijanie z Rzymu nie skorzystali z ich oferty i woleli rokować z barbarzyńcami, co zapoczątkowało dalszy, fatalny rozwój wydarzeń, którego najlepszym symbolem było opisane przez Zosimosa z najwyższym oburzeniem stopienie na okup dla Alaryka wraz z innymi ozdobami i posagami dawnych bogów także posagu bogini Virtus ${ }^{54}$. A przecież Alaryk nie był obojętny na znaki dane od bogów. Już w 395 r., jak relacjonuje Zosimos, gdy zbliżał się do Aten z zamiarem złupienia i zniszczenia miasta, zląkł się broniących murów grodu Pallas Ateny oraz ducha Achillesa i nie tylko niecnych zamiarów poniechał, ale nawet jako dostojny gość odwiedził w otoczeniu niewielkiej eskorty miasto córy Zeusa, gdzie cieszył się kąpielą i wytworną dyskusją z ojcami miasta ${ }^{55}$. Skoro nawet barbarzyńca szanował bogów, to brak szacunku ze strony imperatorów i ich popleczników musiał przynieść fatalne skutki. Atak Alaryka na Rzym był wynikiem nieudolności i zbrodni chrześcijańskiego rządu Olimpiusza i chwiejności Honoriusza, który odmówił Alarykowi oczekiwanych niewielkich subsydiów i, miast po upadku Stilichona (także dzieło przewrotnego chrześcijanina Olimpiusza, ale i kara bogów) oddać dowództwo doświadczonemu Sarusowi, mianował na to stanowisko nieudolnych oficerów. W konsekwencji Alaryk szydząc z tych przygotowań ruszył na Rzym ${ }^{56}$. Stilichon wprawdzie był zdolny powstrzymać Alaryka, ale dopuścił się czynów bezbożnych, co doprowadziło do jego upadku. Kara dosięgła go m.in. za rabunek złotych obić drzwi świątyni kapitolińskiej. Podobnie było z jego żoną Sereną, która zabrała naszyjnik bogini Rei, a to bluźnierstwo sprawiło, że została potem, już w czasie oblężeń Miasta, uduszona z wyroku senatu,

${ }^{53}$ Por. tamże IX 10, 1-4, GCS NF 4, 401, 27 - 402, 13.

${ }^{54}$ Por. Zosimos, Historia nova V 41, 1-3, ed. L. Mendelssohn, Lipsiae 1887, 269, 22 - 270, 21.

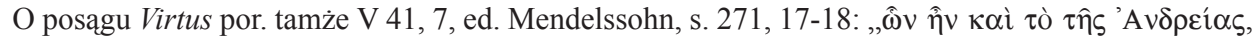

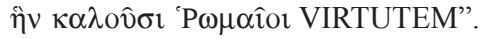

${ }^{55}$ Por. tamże V 6, 1-2, ed. Mendelssohn, s. 222, 21 - 223, 10.

${ }^{56}$ Por. tamże V 36, 1-7, ed. Mendelssohn, s. 263, 4 - 264, 6; V 37, 1, ed. Mendelssohn, s. 264, 7-13. 
jako podejrzana o knowania z barbarzyńcami ${ }^{57}$. Zginął też ich syn Eucheriusz. Zosimosowi zawdzięczamy najdokładniejszy opis dwóch pierwszych oblężeń Rzymu. Trzeciego nie zdążył opisać. Tylko od niego dowiadujemy się o przebiegu rokowań między rzymskimi posłami a Alarykiem w 408 r., gdy negocjowano okup ${ }^{58}$. Poznajemy powody ponownego ataku na Rzym w 409 r., okoliczności uzurpacji Atallusa i wielki głód spowodowany odcięciem dostaw zboża z Afryki ${ }^{59}$. Autor wspomina też o obecności Galli Placydii w otoczeniu Alaryka w 409 r. Miała ona już wtedy być zakładniczką króla, choć otaczano ją najwyższą czcią i szacunkiem należnym jej pochodzeniu ${ }^{60}$. Dzieło Zosimosa kończy się na roku 409, a więc brak w nim relacji o trzecim oblężeniu i złupieniu Miasta w 410 r., a to stanowi niewątpliwie dużą stratę dla badaczy epoki. Stałym przesłaniem kryptopogańskiego historyka było, że powodem nieszczęścia Italii i Rzymu w latach 408/409 były złe rządy i krótkowzroczność chrześcijańskich władców oraz wzgarda dla tradycyjnej religii.

Niezawodny w wielu innych przypadkach Prokopiusz z Cezarei (ok. 500 - ok. 554) w odniesieniu do wydarzeń z lat 408-410 nie imponuje ani bogactwem, ani precyzją przekazu. Wszystkie trzy oblężenia łączy w jedno, a jako powód główny całego nieszczęścia wymienia brak stałości barbarzyńców, którzy nie potrafią dochować wierności. Motyw ten, będący w literaturze późnoantycznej niemal stałym toposem w kontekście zdobycia Rzymu, pojawia się tylko u Prokopiusza. Jego zdaniem Wizygoci po przybyciu znad Dunaju zawarli foedus z Arkadiuszem, ale ich przewrotna natura nie pozwoliła na zachowanie przymierza ${ }^{61}$. Zwrócili się przeciw Honoriuszowi, a ponieważ ten nie umiał ich powstrzymać spustoszyli i wyludnili całą Italię ${ }^{62}$. Oblegli też Rzym, jednak oblężenie trwało długo, więc Alaryk postanowił zdobyć Miasto podstępem. Celem jego uskutecznienia darował senatorom rzymskim trzystu młodzieńców gockich jako niewolników, udając przy tym, że zamierza odstapić od oblężenia. O oznaczonej porze młodzi agenci Alaryka wymordowali strażników u Bramy Salaryjskiej i wpuścili Gotów do Rzymu ${ }^{63}$. Według drugiej z podanych przez Prokopiusza wersji biegu wydarzeń bramy Rzymu otwarła Wizygotom pobożna wdowa Proba (a raczej rozkazała otworzyć swoim służącym), która nie mogła znieść szerzącego się w Rzymie kanibalizmu spowodowanego głodem ${ }^{64}$. Prokopiusz informuje, że Goci spalili Rzym i wymordowali większość mieszkańców ${ }^{65}$. Zupełnie achronologicznie historyk

\footnotetext{
${ }^{57}$ Por. tamże V 38, 1-5, ed. Mendelssohn, s. 265, 20 - 267, 8.

${ }^{58}$ Por. tamże V 40, 1-4, ed. Mendelssohn, s. 268, 8 - 269, 21.

${ }^{59}$ Por. tamże VI 1-13, ed. Mendelssohn, s. 282, 1 - 294, 4.

${ }^{60}$ Por. tamże VI 12, 3, ed. Mendelssohn, s. 293, 7-9.

${ }^{61}$ Por. Procopius Caesariensis, De bellis III 2, 7, ed. J. Haury - G. Wirth, w: Procopius Caesariensis, Opera omnia, vol. 1, Lipsiae 1962, 311, 24 - 312, 2.

${ }^{62}$ Por. tamże III 2, 12, ed. Haury - Wirth, s. 312, 21-25.

${ }^{63}$ Por. tamże III 2, 14-23, ed. Haury - Wirth, s. 313, 3 - 314, 19.

${ }^{64}$ Por. tamże III 2, 27, ed. Haury - Wirth, s. 315, 10-18.

${ }^{65}$ Por. tamże III 2, 24, ed. Haury - Wirth, s. 314, 23-24. Ta wiadomość koliduje z większością
} 
z Cezarei lokuje uzurpację Atallusa i próbę zajęcia Afryki podjętą w roku 409 dopiero po opuszczeniu przez Gotów zniszczonego Rzymu, czyli późnym latem 410 roku $^{66}$. Kolejnym wyjątkiem na tle innych relacji jest bardzo surowa ocena cesarza Honoriusza. Wprawdzie z innych źródeł opisujących wydarzenia 408-410 r. można się dowiedzieć, że genialnym wodzem ani wybitnym władcą Honoriusz nie był, ale Prokopiusz zrobił z niego skończonego idiotę, który na wieść o upadku Rzym ('P $\omega \mu \eta \eta \dot{\alpha} \pi$ ó $\omega \lambda \lambda \varepsilon$ ) miał ogromnie rozpaczać, sądząc, że zdechła jego ulubiona kura o imieniu Roma (Rzym), a gdy eunuch pałacowy wyprowadził go z błędu i uświadomił, że chodzi o zdobycie i zniszczenie Miasta, cesarz miał odetchnąc z ulgą ${ }^{67}$.

Najmniej precyzyjne i niezgodne ze znanymi faktami informacje pozostawił Jan Malalas (491-578). Jego zdaniem to cesarz Honoriusz chcąc zdławić bunt jaki wybuchł przeciw jego władzy w Rzymie skierował do Miasta, celem poskromienia buntowników, Alaryka, pozostającego wówczas w Galii jako

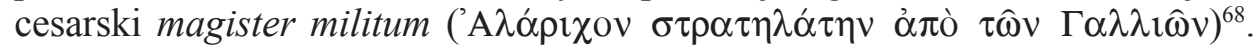
Król Wizygotów wkroczył do Miasta nie czyniąc krzywdy mieszkańcom zbuntowanym przeciw cesarzowi, wtargną jednak do pałacu cesarskiego i zabrał stamtąd wszystkie skarby oraz siostrę przyrodnia cesarza Honoriusza Gallę Placydię. Dalszą część relacji Malalas poświęca późniejszym losom cesarskiej siostry, pomijając jednak całkowicie jej małżeństwo z Ataulfem, a informując jedynie o późniejszym związku małżeńskim z Konstancjuszem III († 2 IX 421, cesarz od 8 II 421$)^{69}$. Alaryk istotnie miał być wysłany do Galii przeciw uzurpatorowi Konstantynowi III, jednak wobec śmierci Stilichona i późniejszych zawirowań politycznych nigdy nie przekroczył Alp, nie mógł więc wyruszyć z Galii przeciw Rzymowi i nie czynił tego z rozkazu Honoriusza. Informacja o buncie Rzymian może być reminiscencją uzurpacji Atallusa, który zresztą wymieniany jest $\mathrm{w}$ dalszej części narracji Malalasa jako jeden z czterech pokonanych przez magistra militum Konstancjusza (późniejszego Konstancjusza III $)^{70}$. Krótka relacja o splądrowaniu Rzymu, ale oszczędzeniu mieszkańców nie odbiega od wcześniejszych opisów.

2. Gisericus intra portas - 455 rok. Zdobycie i dwutygodniowa grabież Rzymu dokonane przez Gejzeryka króla Wandalów i Alanów, podobnie jak w przypadku wydarzeń 408-410 r. ${ }^{71}$ budziły emocje i dyskusje wśród history-

innych relacji, które co prawda mówią o rabunkach i podpaleniach, ale są na ogół zgodne co do tego, że straty w ludziach nie były duże i podkreślają, że zdobywca uszanował azyl kościelny.

${ }^{66}$ Por. tamże III 2, 28-30, ed. Haury - Wirth, s. 315, 18 - 316, 2.

${ }^{67}$ Por. tamże III 2, 25-26, ed. Haury - Wirth, s. 314, 25 - 315, 9.

${ }^{68}$ Ioannes Malalas, Chronographia XIII 46, rec. L. Dindorfius, CSHB [11], Bonnae 1831, 349, 14

${ }^{69}$ Por. tamże XIII 46-47, CSHB [11], 349, 15 - 350, 8.

${ }^{70}$ Por. tamże XIII 47, CSHB [11], 350 8-11.

${ }^{71}$ Podobnie jak w części poświęconej latom 408-410 tak i tutaj podaję najważniejsze prace monograficzne zawierające fragmenty analizujące sacco di Roma z 455 r., wydane w ciągu ostatnich 20 lat z zaznaczeniem właściwych fragmentów: D. Henning, Periclitans res publica. Kaisertum 
ków. W zachodniej, łacińskiej historiografii fakt ponownego zdobycia Miasta przez barbarzyńców jest oczywiście odnotowywany, ale często są to jedynie informacje kronikarskie, bez komentarza i narracji, i jako takie nie wchodzą w zakres tematyki tego artykułu. Łaciński Zachód pozostawił tylko dwie obszerniejsze relacje na temat tego wydarzenia. Historiografia wschodniorzymska ma w tym względzie do zaoferowania znacznie więcej.

Najbliższy wypadków i zarazem najbardziej wiarygodny, jeżeli chodzi o ogólny bieg zdarzeń jest św. Prosper z Akwitanii, znany lepiej historykom jako Prosper Tiro (ok. 390 - ok. 455/456), który będąc sekretarzem papieża Leona I Wielkiego (ok. 390/400 - 10 XI 461, papież od 29 IX 440) był nie tylko komentatorem, ale z pewnością także i świadkiem interesujących nas wydarzeń. Jego zwięzła relacja może stanowić wzorcowy opis wydarzeń, do którego zostaną przyrównane kolejne z omawianych narracji. Punktem wyjścia jest według Prospera mord dokonany 21 września 454 r. na Flawiuszu Aecjuszu (* ok. 390) przez cesarza Walentyniana III (2 VII 425 - 16 III 455, cesarz od $425)^{72}$. W marcu 455 r. z kolei został zamordowany Walentynian III (Prosper nie podaje bliższych informacji o mordercach). Po władzę sięgnął wówczas Petroniusz Maksimus (ok. 396 - 31 V 455, cesarz od 17 III 455), vir gemini consulatus et patriciae dignitatis, który poślubił wdowę po Walentynianie III, Licynię Eudoksję (422-462) ${ }^{73}$. Wiadomości o wydarzeniach w Rzymie sprowokowały Gejzeryka, króla Wandalów i Alanów, do interwencji. Na wieść o zbliżaniu się armii wandalskiej do Rzymu Petroniusz Maksimus postanowił ratować się ucieczką, lecz został rozdarty na sztuki przez rozwścieczonych ludzi z jego otoczenia. Pozostawione samemu sobie Miasto uratowała odwaga

und Eliten in der Krise des Weströmischen Reiches 454/5-493 n. Chr., Historia. Einzelschriften 133, Stuttgart 1999, 16-27; H. Castritius, Die Vandalen. Etappen einer Spurensuche, Stuttgart 2007, 105-110; Halsall, Barbarian Migrations, s. 254-256; Demandt, Die Spätantike, s. 142-143; F. Anders, Flavius Ricimer. Macht und Ohmacht des weströmischen Heermeisters in der zweiten Hälfte des 5 Jahrhunderts, Frankfurt am Main 2010, 453-466; A. Merrills - R. Miles, The Vandals, Chichester 2010, 116-119; K. Vössing, Das Königreich der Vandalen. Geiserichs Herrschaft und das Imperium Romanum, Darmstadt 2014, 55-59; Y. Modéran, Les vandales et l'Empire Romain, Arles 2014, 187-189; I. Hughes, Patricians and Emperors. The Last Rulers of theWestern Roman Empire, Barnsley 2015, 39-48; M. Wilczyński, Gejzeryk $i$ „,czwarta wojna punicka”, Oświęcim 2016, 145-156; R. Steinacher, Die Vandalen. Aufstieg und Fall eines Barbarenreichs, Stuttgart 2016, 196-206; I. Hughes, Gaiseric. The Vandal Who Destroyed Rome, Barnsley 2017, 133-142.

${ }^{72}$ Najlepiej o okolicznościach zamordowania Aecjusza i o jego znaczeniu: T. Stickler, Aëtius. Gestaltungsspielräume eines Heermeisters im ausgehenden Weströmischen Reich, München 2002, 70-83 i 305-319.

${ }^{73}$ Por. Prosperus Tiro Aquitanus, Chronicon 1375, ed. M. Becker - J.-M. Kötter: Proper Tiro, Chronik. Laterculus regum Vandalorum et Alanorum, Kleine und fragmentarische Historiker der Spätantike. G 5-6, Paderborn 2016, 136. Prosper surowo oceniał charakter Maksimusa, który nie tylko nie ukarał morderców Walentyniana, ale wręcz obdarzył ich przyjaźnią: ,si quidem interfectores Valaentiniani non solum non plecerit, sed etiam in amicitiam receperit". Na temat Petroniuszu Maksimusie por. Hughes, Patricians and Emperors, s. 39-48, a wcześniej: Henning, Periclitans res publica, s. 28-32. 
papieża Leona I Wielkiego, który negocjując z królem u bram Rzymu uzyskał obietnicę, że Wandalowie powstrzymają się od mordowania i torturowania mieszkańców ${ }^{74}$. Po 14 dniach rabunku Gejzeryk opuścił metropolię nad Tybrem z ogromnym łupem, tysiącami jeńców i cum regina et filiabus eius, czyli z cesarzową Licynią Eudoksją i jej dwoma córkami Eudocją (439 - 466/474?) i Placydią (V w.) $)^{75}$.

Kolejnym dziejopisem, żyjącym współcześnie z wydarzeniami 455 r., był Priskos z Panion (ok. 410/420 - przed 472/474), wschodniorzymski dyplomata, wsławiony przede wszystkim opisem poselstwa wysłanego przez cesarza Teodozjusza II na dwór Attyli, króla Hunów († 453, król Hunów od 434, panowanie samodzielne od 444/445). Posłował też w 450 r. do Aecjusza. Jak wiadomo $\mathrm{z}$ jego traktatu historycznego zachowały się $\mathrm{w}$ dziełach innych autorów jedynie fragmenty, ale szczęśliwie są wśród nich i te traktujące o wydarzeniach 455 r. Relacja Priskosa nie ma wprawdzie waloru opowieści naocznego świadka, jak w przypadku Prospera, ale wydaje się równie wiarygodna. Priskos korzystał ze źródeł informacji dostępnych wschodniorzymskiej dyplomacji, która była żywotnie zainteresowana działaniami króla Gejzeryka, uważanymi za zagrażające bezpieczeństwu i istotnym interesom dworu w Konstantynopolu. Już pierwsze zdanie fragmentu poświęconego wydarzeniom 455 r.: "O $\tau \imath \tau \grave{\alpha}$

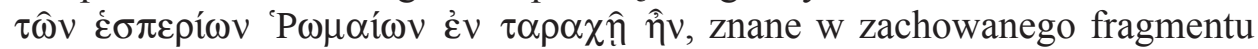
kroniki Jana z Antiochii (VI/VII w.) ${ }^{76}$, sygnalizuje dystans autora do wydarzeń na Zachodzie. Jest to raczej pozycja zewnętrznego obserwatora, a nie osoby głęboko personalnie zaangażowanej w sprawy dalekich hesperyjskich części coniunctissimi imperii. Relacja Priskosa jest bogatsza od Prosperowej i nakreślony jest w niej nie tylko przebieg wydarzeń, ale i szersze tło polityczne. Historyk twierdzi, że pochodzący z senatorskiego rodu Petroniusz Maksimus wraz z eunuchem dworskim Herakliuszem († 16 III 455) popchnęli cesarza Walentyniana III do zamordowania Aecjusza ${ }^{77}$. Potem jednak cesarz nie nadał Maksimusowi oczekiwanej przez niego godności patrycjusza (podobno za podszeptami eunucha), więc Maksimus miał zachęcić związanych z Aecjuszem oficerów, niejakiego Optylę i Traustylę, do zamachu na Walentyniana

${ }^{74}$ Por. Prosperus Tiro Aquitanus, Chronicon 1375, ed. Becker - Kötter, s. 138.

${ }^{75}$ Por. tamże.

${ }^{76}$ Priscus, Fragmenta 30, 1 (1), ed. R.C. Blockley, w: The Fragmentary Classicising Historians of the Later Roman Empire. Eunapius, Olympiodorus, Priscus and Malchus, vol. 2: Text, Translation and Historiographical Notes, ARCA Classical and Medieval Texts, Papers and Monographs 10, Liverpool 1983, 326. Tekst zachowany w: Ioannes Antiochenus, Fragmenta quae supersunt omnia 224, 1, rec. S. Mariev, Berolini 2008, 404. (w tej edycji brak słowa $\varepsilon \sigma \pi \varepsilon p i ́ \omega v)$ ). Zarówno Roger C. Blockley, jak i Sergei Mariev sformułowanie દ̉v $\tau \alpha \rho \alpha \chi \hat{n} \hat{\eta} v$ thumaczą were in turmoil, czyli, że sprawy Rzymian zachodnich „były pogrążone w chaosie”, co może i dobrze

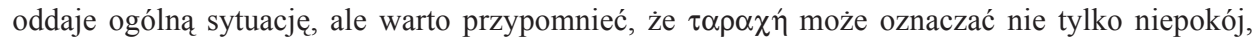
wzburzenie, zakłócenia czy chaos, ale także zamieszki polityczne, rozruchy, tumult oraz, co także pasuje do przebiegu wydarzeń, zamęt bitewny, walkę lub starcie.

${ }^{77}$ Por. tamże 30, 1 (1-8), ed. Blockley, s. 326. 
III, który przeprowadzono skutecznie 16 marca 455 r., kiedy to na Campus Martius Optyla i Traustyla zasiekli Walentyniana III, a Traustyla zamordował jeszcze Herakliusza i dostarczył diadem zdjęty ze zwłok cesarza i cesarskiego rumaka Maksimusowi, który uzurpował sobie władzę cesarską ${ }^{78}$. Gejzeryk miał wykorzystać okazję do ataku na Rzym, wiedząc o słabości militarnej uzurpatora $^{79}$. Priskos przytacza jeszcze inne wythumaczenie przyczyny najazdu Gejzeryka, choć ostrożnie się od tej tezy dystansuje, używając formuły: oi

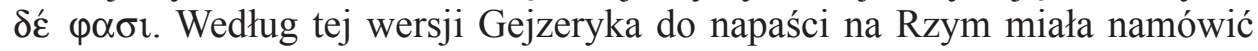
cesarzowa wdowa Licynia Eudoksja, zmuszona do poślubienia uzurpatora, sprawcy mordu na jej mężu ${ }^{80}$. Flota Gejzeryka wylądowała pod Azestus, nie-

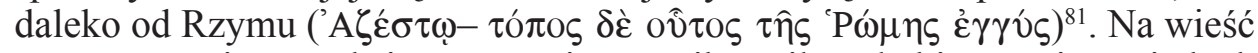
o tym Petroniusz Maksimus ogarnięty paniką usiłował zbiec z Miasta, jednak został rozerwany na sztuki przez własną gwardię i rozwścieczony tłum, a król Wandalów wkroczył do Miasta ${ }^{82}$. Ostatnią informacją jest krótki opis starań poselstwa cesarza wschodniego Marcjana o uwolnienie z Kartaginy żony Walentyniana III i jego córek, uprowadzonych przez Gejzeryka po splądrowaniu Rzymu wraz z innymi jeńcami ${ }^{83}$. Jak widać relacja Priskosa wzbogaca o kilka

${ }^{78}$ Por. tamże 30, 1 (51-72), ed. Blockley, s. 328 i 330. Mord był jawny i wyjątkowo brutalny. Optyla jako pierwszy ciął Walentyniana III z boku w głowę, a gdy cesarz się zachwiał wymierzył kolejne cięcie tym razem przez twarz (por. tamże 30, 1 (62-65), ed. Blockley, s. 330).

${ }^{79}$ Por. tamże 30, 1 (83-87), ed. Blockley, s. 330.

${ }^{80}$ Por. tamże 30, 1 (87-90), ed. Blockley, s. 330. Informacja ta powtarzana później także przez inne źródła jest w zasadzie dość prawdopodobna, choć nie sposób dowieść, że istniało bezpośrednie wezwanie pomocy. Możliwe też, że Gejzeryka wcale nie trzeba było prosić. Istniały przecież co najmniej od lat 50-tych V w. związki sojusznicze i familijne pomiędzy domem królewskim Asdingów a domem Teodozjańskim na Zachodzie. Po zawarciu pokoju w roku 442 doszło do zaręczyn córki Walentyniana III, Eudocji, i syna Gejzeryka, Huneryka (ten ostatni oddalił nawet w tym celu swoją dotychczasową żonę, córkę wizygockiego króla Teodoryka I († 451, król od 418), brutalnie okaleczoną pod zarzutem spisku przeciw Gejzerykowi). Król Wandalów, jakkolwiek by na to nie patrzeć, formalnie, a szczególnie gdy przynosiło to korzyści, był przyjacielem i sojusznikiem zamordowanego cesarza Walentyniana III (wprost mówił o tym później Prokopiusz w De bellis III 4, 39, ed. Haury - Wirth, s. 331, 5-7), a plany wydania Eudocji za Palladiusza († 455?), syna uzurpatora Maksimusa, godziły w dynastyczne i polityczne plany Gejzeryka. Obrona rodziny Walentyniana III była więc wygodnym pretekstem dla uczynienia kolejnego kroku w kierunku osłabienia Cesarstwa Zachodniego i milowym krokiem ku wymuszeniu uznania pełnej suwerenności afrykańskiego królestwa Wandalów. Por. F.M. Clover, Geiseric the Statesman. A Study of Vandal Foregin Policy, Chicago 1966 (Dissertation), 147; Henning, Periclitans res publica, s. 25; Demandt, Die Spätantike, s. 142-143; Hughes, Gaiseric, s. 135-137. Więcej o samych zaręczynach Huneryka i Eudocji i ich datacji: Wilczyński, Gejzeryk i ,czwarta wojna punicka”, s. 132-136.

${ }^{81}$ Priscus, Fragmenta 30, 1 (90-91), ed. Blockley, s. 330 i 332. Tylko Priskos, a za nim Jan z Antiochii podają nazwę miejsca lądowania Gejzeryka w Italii.

${ }^{82}$ Por. tamże 30, 1 (91-100), ed. Blockley, s. 332.

${ }^{83}$ Por. tamze 31, 1 (1-8), ed. Blockley, s. 332. Oczywiście kobiety domu cesarskiego nie były traktowane w Kartaginie jak zwykli jeńcy, tym bardziej, że sfinalizowano wreszcie dawno już planowane małżeństwo starszej córki Walentyniana, Eudocji, z synem Gejzeryka Hunerykiem († 484, król Wandalów i Alanów od 25 I 477). Ostatecznie w późniejszym czasie Gejzeryk zezwolił na wy- 
szczegółów to, co wiemy już od Prospera. Wschodniorzymski dyplomata pomija natomiast całkowitym milczeniem bohaterskie działania papieża Leona I Wielkiego i jego zasługę dla uratowania mieszkańców Miasta przed śmiercią i torturami. Z punktu widzenia Konstantynopola nie był to fakt politycznie znaczący i godny odnotowania, a może Priskos po prostu o rokowaniach Leona z Gejzerykiem nie wiedział. Relację Priskosa wykorzystali Jordanes i Jan z Antiochii, wywarła też ona znaczący wpływ na dzieła Prokopiusza z Cezarei i Ewagriusza Scholastyka (532/537 - po 593/594).

Prokopiusz z Cezarei dodał od siebie kilka uzupełnień. Nie tylko wspomina, że Petroniusz Maksimus pochodził z rodu senatorskiego, ale jeszcze wyjaśniał, że był to ten sam ród, który wydał uzurpatora Magnusa Maksymusa (ok. 340 - 28 VII lub VIII 388, cesarz od wiosny 383) ${ }^{84}$ Dalej jednak odchodzi od schematu Priskosa twierdząc, że powody spisku Maksymusa przeciw Walentynianowi III były nie natury politycznej, ale osobistej. Cesarz pragną nieznanej nam z imienia żony Maksymusa i zwabiwszy ją oszukańczo do pałacu posiadł gwałtem, o czym zgwałcona ze łzami poinformowała swojego męża ${ }^{85}$. Ten zaprzysiągł zemstę i najpierw, by pozbawić Walentyniana III najsilniejszej podpory jego władzy, nakłonił go do zamordowania Aecjusza, przez co znacznie osłabił pozycję cesarza ${ }^{86}$. Po zaczerpniętej również z Priskosa, ale mylnie, anachronicznie uplasowanej dygresji na temat wojny prowadzonej w Italii przez Attylę po zamordowaniu Aecjusza i szczegółowym opisie oblężenia Akwilei przez Hunów ${ }^{87}$, Prokopiusz lakonicznie informuje, że Maksymus bez trudu zabił cesarza, poślubił wdowę po nim, czyli Licynię

jazd z Afryki Licynii Eudoksji wraz z młodszą córką Placydia, a Huneryk uczynił potem podobnie ze swą żoną Eudocją, lecz stało się to już po narodzinach ich syna, późniejszego króla Wandalów i Alanów Hilderyka (ok. 560? - 533, król w latach 523-530).

${ }^{84}$ Por. Procopius Caesariensis, De bellis III 4, 16, ed. Haury - Wirth, s. 327, 3-7. Z punktu widzenia Prokopiusza wykazanie, że przyszły uzurpator był krewnym uzurpatora z IV w. było informacją cenną i wpisującą się w opinie o uzurpatorach ferowane przez historiografię konstantynopolitańską. Dodatkowo budowaniu sugestii o „dziedzicznym obciążeniu” Petroniusza Maksimusa

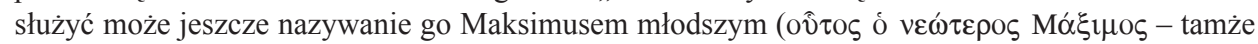
III 4, 17, ed. Haury - Wirth, s. 327, 7).

${ }^{85}$ Por. tamże III 4, 17-23, ed. Haury - Wirth, s. 327, 7 - 328, 5.

${ }^{86}$ Por. tamże III 4, 24-27, ed. Haury - Wirth, s. 328, 5-20. Znamienna jest przytoczona przez Prokopiusza zaraz w następnym akapicie opinia nieznanego Rzymianina, który pytany przez cesarza, czy słusznie uczynił pozbawiając życia Aecjusza odpowiedział, że tego nie wie, wie natomiast, że w ten sposób cesarz ręką lewą odrąbał sobie rękę prawą (por. tamże III 4, 28, ed. Haury - Wirth, s. $328,20-329,2)$.

${ }^{87}$ Por. tamże III 4, 29-35, ed. Haury - Wirth, s. 329, 3 - 330, 13; Priscus, Fragmenta 22, 2, ed. Blockley, s. 312 i 314. Attyla zmarł przed zamordowaniem Aecjusza, a opisany najazd na Italię miał miejsce rok przed śmiercią Aecjusza. U Jordanesa, który też korzysta z przekazu Priskosa, nie występuje omyłka chronologiczna podobna do tej u Prokopiusza. Najpierw jest tu relacja o działaniach Attyli (por. Jordanes, De origine actibusque Getarum 219-224, MGH Auctores Antiquissimi V/1, 114, 3 - 115, 19), a dopiero później o śmierci Walentyniana III i przybyciu Gejzeryka do Italii (por. tamże 235, MGH Auctores Antiquissimi V/1, 118, 3-8). 
Eudoksję, i sprawował władzę tyrańską ${ }^{88}$. Jako motyw najazdu Gejzeryka Prokopiusz bez wahania podaje rozwinięty motyw zemsty cesarzowej Eudoksji, która wątpiła w ewentualną pomoc z Konstantynopola, a Gejzeryka wzywa-

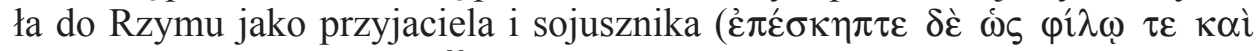

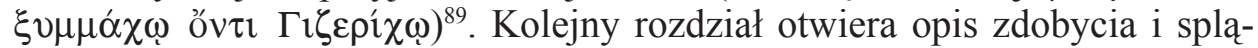
drowania Rzymu przez Gejzeryka. Nie ma żadnej wzmianki o mediacji Leona I Wielkiego, jest tylko powiedziane, że król Wandalów i Alanów wkroczył do Miasta nie napotkawszy żadnego oporu ${ }^{90}$. Petroniusza Maksimusa Rzymianie nie rozdarli na sztuki, ale ukamienowali przy próbie ucieczki, a jego ciało porąbali na kawałki, jednak nie jest wymieniona konkretna grupa sprawców (np. żołnierze, lud, itp. $)^{91}$ Prokopiusz podaje też więcej szczegółów odnośnie złupienia Miasta. Wspomina o ograbieniu dawnej świątyni Jowisza Kapitolińskiego i zdarciu z niej części dachu, jak też daje wyobrażenie o skali rabunków pisząc, że wywożono z Miasta takie ilości dzieł sztuki, że nawet jeden ze statków nadmiernie przeładowany posagami zatoną ${ }^{92}$. Informuje też o uprowadzeniu do Kartaginy cesarzowej wdowy Eudoksji wraz z córkami, Eudocją i Palcydią ${ }^{93}$. Ostatnia informacja dotyczy wydania w Kartaginie Eudocji za księcia Huneryka i późniejszego odesłania Eudoksji i Placydii wraz z mężem Olybriuszem do Konstantynopola ${ }^{94}$.

Jak już wspomniano Jan z Antiochii wykorzystał relację Priskosa, którą znamy w przytoczonej powyżej formie dzięki zachowanemu obszernemu fragmentowi Janowej kroniki ${ }^{95}$. Zasób i układ informacji w tym fragmencie został dokładnie omówiony przy relacji Priskosa.

Mimo że Jordanes, historyk o gockich korzeniach, swoje dzieło historyczne De origine actibusque Getarum pisał z gockiej perspektywy, podążając za swoim niedoścignionym wzorem Aureliuszem Kasjodorem (ok. 485-583), to jednak tworzył on w oparciu o dostępne w Konstantynopolu źródła oraz korzystał ze streszczanych przez siebie dwunastu ksiagg historii gockiej Kasjodo$\mathrm{ra}^{96}$. Niewielki akapit poświęcony zdobyciu Rzymu zawiera informacje znane z zachowanych fragmentów Priskosa, ale i pokrywające się z relacją Prospera

${ }^{88}$ Por. Procopius Caesariensis, De bellis III 4, 36, ed. Haury - Wirth, s. 330, 14-16. Brak jakichkolwiek bliższych informacji o okolicznościach śmierci Walentyniana III.

${ }^{89}$ Tamże III 4, 39, ed. Haury - Wirth, s. 331, 5.

${ }^{90}$ Por. tamże III 5, 1, ed. Haury - Wirth, s. 331, 11-14.

${ }^{91}$ Por. tamże III 5, 2, ed. Haury - Wirth, s. 331, 15-17.

${ }^{92}$ Por. tamże III 5, 3-5, ed. Haury - Wirth, s. 331, 20 - 332, 9.

${ }^{93}$ Por. tamże III 5, 3, ed. Haury - Wirth, s. 331, 17-19. Prokopiusz nie upiększa rzeczywistości, tylko pisze wprost, że Gejzeryk wziął je do niewoli - $\alpha i \chi \mu \alpha \dot{\alpha} \lambda \omega \tau$ ov $\varepsilon \hat{i} \lambda \varepsilon$.

${ }^{94}$ Por. tamże III 5, 6, ed. Haury - Wirth, s. 332, 9-13.

${ }^{95}$ Ioannes Antiochenus, Fragmenta quae supersunt omnia 224, 1-4, rec. Mariev, s. 404, 406, 408, 410 i 412.

${ }^{96}$ Por. Jordanes, De origine actibusque Getarum 1, MGH Auctores Antiquissimi V/1, 53, 6-8: „ut nostris verbis duodecem Senatoris volumina de origine actusque Getarum ab olim et usque nunc per generationes regesque descendentem in uno et hoc parvo libello choartem". 
Tiro. Jordanes pisze lakonicznie, że Walentynian III został podstępnie zgładzony przez Petroniusza Maksimusa (nie podaje szczegółów i nic też nie pisze o Optyli i Traustyli), który sięgnął po władzę tyrańską. Na wieść o tym Gejzeryk podejmuje wyprawę na Rzym i wkroczywszy do Miasta wszystko pustoszy (Quod audiens Gyzericus rex Vandalorum ab Africa armata classe in Italiam venit Romaeque ingressus cuncta devastat). Oryginalna jest tylko wersja śmierci Petroniusza Maksimusa, który podczas ucieczki nie został, zdaniem Jordanesa, zabity przez rozwścieczony thum, ale przez rzymskiego żołnierza imieniem Ursus ${ }^{97}$. W De summa temporum vel origine actibusque gentis Romanorum Jordanes ewidentnie wykorzystuje relacje zaczerpnięte bezpośrednio lub pośrednio od Priskosa ${ }^{98}$. Wprawdzie w dużym skrócie, ale zamieszcza wszystkie najważniejsze wątki: zdradę Petroniusza Maksimusa, który doprowadził do zabicia Aecjusza zainspirowany przez eunucha Herakliusza, dokonany przez Optylę i Traustylę mord na Walentynianie III i eunuchu Herakliuszu, trzymiesięczną tyranię Maksimusa, zakończoną rozdarciem uciekającego cesarza przez wściekły tłum (ani słowa o Ursusie), wezwanie Gejzeryka na pomoc przez Licynię Eudoksję, złupienie w Rzymie wszystkiego, co dało się złupić i powrót Wandalów do Afryki wraz z Licynią Eudoksją i jej dwoma córkami (nie wymienia imion) ${ }^{99}$. Ciekawość budzi postać żołnierza Ursusa nieznana z żadnego innego źródła. Może to jakiś ślad tradycji italskiej, zaczerpnięty z zaginionych pism Kasjodora, a może własna inwencja Jordanesa.

Dość obszerną relację wzbogaconą nawet ciekawymi uwagami o naturze rodzaju niewieściego pozostawił Ewagriusz Scholastyk. Zachowując tok narracji zaczerpnięty z Priskosa, którego tekst wykorzystywał pisząc swoją Historię Kościoła, wymienia on wszystkie podstawowe fakty dostępne u historyka-dyplomaty z Panion i u Prokopiusza. Wprowadza też dodatkowo znany już z Prokopiusza wątek uwiedzenia żony Petroniusza Maksimusa przez Walentyniana III ${ }^{100}$. W odwecie Maksimus zmusza wdowę po zamordowanym cesarzu, by go poślubiła, a ona, mszcząc się za naruszenie jej czci niewieściej (a straszna jest w ten sposób zraniona niewiasta! ${ }^{101}$ ), wzywa na pomoc Gejzeryka, którego (to nowość w stosunku do innych relacji) skłania do sojuszu bogatymi darami i obietnicami. Można się domyślać, że wśród owych obietnic mogła się też znaleźć aluzja do późniejszego małżeństwa Eudocji i Huneryka, o czym zresztą Ewagriusz nieco dalej wspomina, ale w świetle innych źródeł jest to anachronizm, ponieważ, jak

${ }^{97}$ Całość opisu: tamże 235, MGH Auctores Antiquissimi V/1, 118, 3-8 (spec. s. 118, 6-7).

${ }^{98}$ Por. Priscus, Fragmenta 30, 3, ed. Blockley, s. 332 = Jordanes, De summa temporum vel origine actibusque gentis Romanorum 334, MGH Auctores Antiquissimi V/1, 43, 8-15.

${ }_{99}$ Por. Jordanes, De summa temporum vel origine actibusque gentis Romanorum 334, MGH Auctores Antiquissimi V/1, 43, 8-15.

${ }^{100}$ Por. Evagrius Scholasticus, HE II 7, 6-8, ed. J. Bidez - L. Parmentier, SCh 542, Paris 2011, 268.

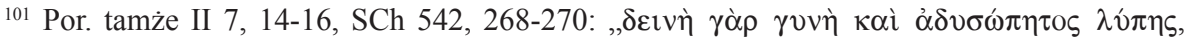

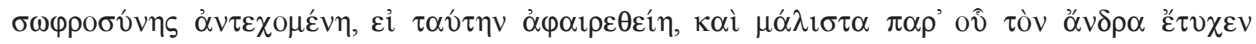
$\dot{\alpha} \pi \mathrm{0} \lambda \varepsilon \dot{\sigma} \sigma \sigma \alpha "$. 
już wspomniano powyżej, zaręczyny małej Eudocji i dorosłego już Huneryka zostały zawarte i potwierdzone jeszcze przed śmiercią Aecjusza, a podjęte przez Petroniusza Maksimusa próby wyswatania Eudocji za jego syna były zapewne jednym z poważniejszych powodów błyskawicznej reakcji militarnej Gejzeryka, broniącego po prostu swoich dyplomatycznych zdobyczy. Licynia Eudoksja nie mogła budzić jego nadziei na przyszłość obietnicami, mogła jedynie bazować na istniejących już wcześniej ustaleniach. Autor nie poświadcza szczególnej kurtuazji króla względem kobiet domu cesarskiego, pisząc, że je „pochwycił” przed powrotem do Afryki ${ }^{102}$. Inną osobliwością u Ewagriusza jest sugestia, że Gejzeryk zwolnił wkrótce Licynię Eudoksję i Placydię, bojąc się gniewu cesarza wschodniego Marcjana (ok. 392 - 27 I 457, cesarz od 25 VIII 450), który miał wpaść w furię na wiadomość o spaleniu Rzymu i zniewadze jaką było uprowadzenie niewiast domu cesarskiego do Kartaginy ${ }^{103}$. Prawdą jest, że Gejzeryk wydał obie wspomniane niewiasty Marcjanowi, ale raczej nie z powodu strachu. Ewagriusz wierny tradycji późnoantycznej historiografii wschodniorzymskiej buduje wizerunek groźnego i potężnego władcy z Konstantynopola, który gotów jest porazić każdego, kto krzywdzi jego zachodnich braci, ale chybia całkowicie. Marcjan wykazywał tak daleko idący brak zainteresowania ewentualnym atakiem na Wandalów, że aż Prokopiusz musiał wynajdywać fantastyczne usprawiedliwienia tej dziwnej słabości u wojennego skądinąd władcy ${ }^{104}$.

Jan Malalas z kolei, bazując na stosunkowo dobrej wiedzy o wypadkach 455 r. zawartej w źródłach i dokumentach wschodniorzymskich, pozostawił relację bardziej ścisłą niż ta dotycząca 408-410 r., choć bogactwem faktów nie dorównał poprzednikom. Swój „ekskurs wandalski” rozpoczyna on od krótkiego wywodu genealogicznego, dotyczącego Licynii Eudoksji, informując następnie, że to ona właśnie, gdy tyran Maksimus zabił jej męża, wezwała Gejzeryka na pomoc. Ten niespodzianie pojawił się pod Rzymem, zdobył Miasto, zabił Maksimusa, wyrżnął mieszkańców i zagrabił wszystko co cenne, pozostawiając jedynie brązy o mniejszej wartości. Wziął też do niewoli pozostałych przy życiu senatorów wraz z cesarzową i jej córkami, i odesłał do Afryki. W Kartaginie wydał Eudokię za Huneryka, a kobiety domu cesarskiego zatrzymał $\mathrm{w}$ honorowej niewoli ${ }^{105}$.

${ }^{102}$ Por. tamże II 7, 16-29, SCh 542, 270. Wydaje się, że Ewagriusz chciał powiedzieć, że cesarzowa wdowa zapraszając Gejzeryka i obiecując mu wydanie Rzymu i Italii w jego ręce liczyła

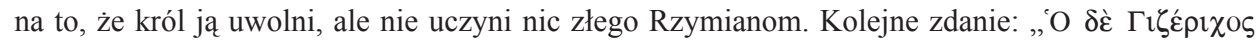

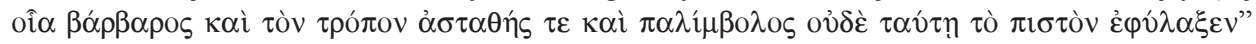
(tamże II 7, 22-23, SCh 542, 270) - zdaje się takie podejrzenie podtrzymywać, ponieważ autor wprowadza topos zdradliwego barbarzyńcy, który w konsekwencji swej niestałości i chytrego charakteru pali i łupi Rzym, a pokładającą w nim nadzieje cesarzową wdowę z córkami porywa do Libii (Afryki). To wydaje się potwierdzać przypuszczenie, że Ewagriusz sugerował, iż Licynia Eudoksja miała nadzieję, że Gejzeryk oszczędzi Miasto.

${ }^{103}$ Por. tamże II 7, 29-37, SCh 542, 270 i 272.

${ }^{104}$ Por. Procopius Caesariensis, De bellis III 4, 1-11, ed. Haury - Wirth, s. 324-326.

${ }^{105}$ Por. Ioannes Malalas, Chronographia XIV 25-26, CSHB [11], 365, 19 - 366, 12. 
Wraz z ostatnią, najpóźniejszą chronologicznie relacją o Gejzerykowym sacco di Roma pióra Pawła Diakona powracamy do kręgu historiografii zachodniej, choć w narracji historyka Langobardów znajdziemy ślad wątków tak zachodnio-, jak i wschodniorzymskich. Powtórzony jest tutaj bowiem motyw zabójstwa Aecjusza i Walentyniana III, jednak bez wyjaśnienia roli Petroniusza Maksimusa w spisku. Jako zabójcę cesarza wymienia się jedynie Transilę (Traustylę) ${ }^{106}$. Krótką informację o przejęciu władzy cesarskiej przez Petroniusza Maksimusa i jego śmierci po dwóch miesiącach sprawowania władzy oraz o przybyciu Gejzeryka do Italii poprzedza dużo obszerniejszy fragment, opisujący rokowania papieża Leona I Wielkiego z Gejzerykiem, w których biskup Rzymu uzyskał obietnicę, że mieszkańcy nie będą mordowani i torturowani. Spora część tego tekstu jest dosłownie przepisana z relacji Prospera Tiro, chętnie wykorzystywanej przez Pawła Diakona, który idąc za swym pierwowzorem wspomina także o czternastodniowym łupieniu Miasta i o tysiącach uprowadzonych jeńców. Wśród nich była regina Eudoksja z córka$\mathrm{mi}^{107}$. Natomiast Paweł Diakon jako jedyny wspomina, że zdobycie i złupienie Rzymu przez Gejzeryka, nastąpiło w 1208 lat ab Urbe condita i było drugim takim wydarzeniem. Poprzedziło je o 44 lata $^{108}$ wcześniejsze zajęcie Miasta przez Alaryka. Nieco później pojawia się informacja, że w Afryce Gejzeryk wydał córkę cesarza Walentyniana (nie podaje jej imienia) za swego syna, przy czym myli imię właściwego pana młodego, księcia Huneryka, z imieniem panującego dużo później króla Trasamunda († 523, król Wandalów i Alanów od 496), bratanka Gejzeryka ${ }^{109}$.

Trzykrotne oblężenie Rzymu przez Wizygotów w latach 408-410 oraz grabież Miasta dokonana po trzecim oblężeniu były dla mieszkańców Italii, jak też innych części Imperium Romanum, rzeczywistym szokiem. Dla wielu było to zapewne sygnałem nadejścia nowych czasów, zdecydowanie bardziej niepewnych i groźnych niż te, które zaliczali do przeszłości. Dotychczasowe najazdy barbarzyńców dotyczyły raczej terenów odległych prowincji pogranicznych , a nawet jeżeli Italii i samemu Miastu jakiś zagon barbarzyński groził, to cesarze i ich wodzowie potrafili niebezpieczeństwu zaradzić. Tak było w czasie wo-

\footnotetext{
${ }^{106}$ Por. Paulus Diaconus, Historia Romana XIV 15, MGH Auctores Antiquissimi II, 206, 6-13.

${ }^{107}$ Por. tamże XIV 16, MGH Auctores Antiquissimi II, 206, 14-24.

${ }^{108}$ Por tamże XIV 17, MGH Auctores Antiquissimi II, 206, 24-27. W istocie o rok więcej, czyli 45 lat. Paweł idzie na pewno za Orozjuszem, którego wyliczenia powtarzał już wcześniej przy komentarzu do zdobycia Rzymu przez Alaryka. Orozjusz zaś za św. Augustynem wyliczał, że Alaryk zajął Rzym w 1164 lata od jego założenia, więc Paweł dodając swoje 44 lata uzyskał wynik 1208.

${ }^{109}$ Por. tamże XIV 19, MGH Auctores Antiquissimi II, 207, 10-13. To nie jedyny przypadek osobliwej popularności Trasamuda. Grzegorz z Tours (30 XI 538 - 17 XI 594) pomylił bowiem z Trasamundem samego Gejzeryka (Gregorius Turonensis, Historiae II 2, ed. B.Krusch - W. Levison, MGH Scriptores Rerum Merovingicarum I/1, 2. Aufl., Hannoverae 1951, 39, 13-15).
} 
jen markomańskich, czy w latach 401-402, gdy Alaryk oblegał Mediolan i walczył ze Stilichonem pod Pollentią. Ten sam scenariusz powtórzył się, gdy dziki Radagais mimo swej siły i brutalności dał głowę pod rzymski miecz w $406 \mathrm{r}$. Dopiero kardynalny błąd jakim było usunięcie Stilichona i dopuszczenie do rządów Olimpiusza doprowadził do wydarzeń o jakich od tysiąca lat z okładem świat nie słyszał. Rzym był wprawdzie już wtedy raczej symbolem dawnej chwały niż centrum administracyjnym Imperium z okresu potęgi cesarstwa. Z kolei dla mieszkańców wschodniej części Imperium centrum politycznym był już od kilkudziesięciu lat Konstantynopol, a Nova Roma w szybkim tempie przerastała starą pod każdym niemal względem. W zachodniej części Imperium Miasto też straciło na znaczeniu. Po wojnie „,pollentyńskiej” cesarz Honoriusz przeniósł siedzibę swego dworu do Rawenny, a wcześniej jeszcze rolę tę pełnił Mediolan. Mimo to jednak Rzym pozostawał nadal siedzibą senatu zachodniorzymskiego oraz miejscem zamieszkania wielu wpływowych przedstawicieli arystokracji rodowej, a więc nadal był on ośrodkiem politycznie ważnym. Trzydniowa grabież Rzymu dokonana przez Wizygotów była, jak już wspomniano, zdarzeniem na tyle szokującym, że dała asumpt do dyskusji nad pytaniem, czy Imperium podąża właściwą drogą. W dziełach zachodniorzymskich odpowiedź na to pytanie, stawiane ze szczególną natarczywością przez kręgi pogańskie, stanowiła absolutny priorytet i zdominowała dyskurs. Bóg wystawił Rzymian na próbę i doświadczył niedolą za ich grzechy, ale okazał miłosierdzie, wybierając jako narzędzie swej woli chrześcijańskiego (choć ariańskiego) i pobożnego Alaryka. Korzystnie odróżniał się on od dzikiego i pogańskiego Radagaisa, szanował świątynie Pańskie, czego najlepszym przykładem jest Orozjuszowy przekaz o wspólnej procesji Rzymian i Gotów, niosących Piotrowe precjoza do świątyni. W dużej mierze zaangażowanie św. Augustyna w dyskurs o roku 410 wpłynęło na przesadnie wysoką ocenę wagi wydarzenia w epokach późniejszych. Przekonanie historyków następnych wieków, że całe Imperium zastygło w zgrozie po wejściu Alaryka do Miasta mocno odbiega od rzeczywistości. Na pewno była to bolesna wiadomość, ale prowincje zachodniorzymskie żyły swoimi problemami. Dla mieszkańców Galii i Hiszpanii bardziej żywotne były tragedie rozgrywające się w miastach ich diecezji, a nadzieją, której się chwytali, nie był Rzym, Rawenna i Honoriusz, lecz uzurpator Konstantyn III, który realnie bronił ich interesów przed barbarzyńcami ${ }^{110}$. Z kolei dla afrykańskich Rzymian realnym problemem byli mauretańscy rabusie i gwałty circumcelliones. Nawet jeżeli pierwsze kazania św. Augustyna wygłaszane w afrykańskich kościołach w latach 410-412 poruszyły słuchaczy, to wkrótce nastapiło znużenie tematem, a nawet obawy, że kwestia ta będzie znów poruszana ${ }^{111}$.

${ }^{110}$ Por M. Kulikowski, Barbarians in Gaul, Usurpers in Britain, „Britania” 31 (2000) 325-345; Delaplace, La fin de l'Empire romain d'Occident, s. 130-138; Janßen, Das weströmische Reich vom Tode des Theodosius bis zur Ermordung Stilichos, s. 202-224; Hughes, Stilicho. The Vandal Who Saved Rom, s. 177-189.

${ }^{111}$ Por. Meier - Patzold, August 410 - ein Kampf um Rom, s. 54. 
Tym bardziej odległym wydawał się problem w dalekim, bezpiecznym Konstantynopolu. Oczywiście tragedia starego Rzymu budziła zainteresowanie, ale na tle wydarzeń w prowincjach Orientu były to sprawy dziejące się bardzo daleko, w tej części świata, która nie ma szczęścia pozostawania pod zbawczymi rządami potężnych augustów Nowego Rzymu. Nawet dziecię na tronie wschodnim zapewnić potrafiło powszechny dobrobyt, a wieść o flocie przez nie wysłanej wprawić miała w panikę zuchwałego Alaryka. Także wschodni dziejopisarze upatrywali w złupieniu Rzymu dopust Boży lub karę za bezbożność, obojętnie czy byli to historycy chrześcijańscy, jak Sokrates i Sozomen, czy pogański Zosimos. Mimo tych tłumaczeń wszyscy relacjonujący odnotowali także okrutne aspekty tych wydarzeń, takie jak długotrwały głód w Mieście i wyniszczenie jego okolic oraz grabież i gwałty dokonywane na mieszkańcach; uprowadzenie pewnej części ludności miasta, a wśród nich cesarskiej siostry; czy wreszcie naruszenie urbanistyczno-estetycznej fasady metropolii nad Tybrem. O namacalnych, politycznych przyczynach nieszczęścia pisano niewiele. Rzeczowo zreferował je tylko Filostorgiusz, wskazując na upadek Stilichona i kryzys centrum dowodzenia, podobnie też uczynił Zosimos, piętnujący Honoriusza za niewłaściwy wybór dowódców po śmierci Stilichona. Równocześnie jako „logiczne” wyttumaczenie pojawiają się spiskowe teorie o próbach zamachu stanu szykowanych przez Stilichona ${ }^{112}$ (Orozjusz, Filostorgiusz, Paweł Diakon) lub o prowokacyjnych atakach magistra militum na poczciwych Gotów (Jordanes i Paweł Diakon). Ogólnie widoczna jest wielość i różnorodność wątków narracyjnych, wtrącanych dygresji czy nawet anegdot, które odbiegają od przyjętego szablonu relacji i ją ubarwiają. Trudno uznać, by autorzy uważali trzydniowy rabunek Rzymu za brzemienny w skutki. Było to dla nich raczej szokujące wydarzenie czy ostrzeżenie, ale na pewno nie krok ku upadkowi rzymskiej cywilizacji ${ }^{113}$.

Inaczej wyglądają relacje o sacco di Roma w 455 r. Pod względem zamieszczanych wiadomości są znacznie bardziej jednorodne niż te dotyczące

${ }^{112}$ We współczesnych publikacjach problem naświetlają m.in.: Wilczyński, Germanie w stuzbie zachodniorzymskiej w V w. n.e., s. 375 -387; Janßen, Das weströmische Reich vom Tode des Theodosius bis zur Ermordung Stilichos, s. 240-259; Hughes, Stilicho. The Vandal Who Saved Rom, s. 202-215.

${ }^{113}$ Rzeczywista, chłodna ocena wydarzeń usprawiedliwia takie podejście. Alaryk i jego następcy, Ataulf oraz Sigeryk ( $\uparrow 415$, król od 415) i Walia ( $\uparrow 418$, król od 415), mimo że stanowili potencjalne zagrożenie dla bezpieczeństwa państwa, nie dokonali żadnych trwałych podbojów i nawet, mając $\mathrm{w}$ pewnych momentach bardzo silne narzędzia nacisku na cesarza, ograniczali swoje ambicje do dostaw zaopatrzenia, nadania rzymskich godności wojskowych, a w dalszej perspektywie do nadań ziemi na zasadach foedus. Formalnie zatem, a po części także praktycznie, pozostawali klientami i beneficjentami Imperium, którzy nawet jeżeli sięgali po miecz, to raczej w celu zwiększenia benefitów, a nie rozdzierania Imperium. Mniej spolegliwi bywali późniejsi władcy Wizygotów, ale tego przynajmniej część piszących o wydarzeniach 410 r. wiedzieć nie mogła. Na temat charakteru działań Alaryka i dość wąskich perspektywach planowanych celów por. Wolfram, Die Goten, s. 166-168 (a dalej o ocenie działań Ataulfa i Walii, tamże, s. 168-177); Heather, Upadek Cesarstwa Rzymskiego, s. 264-267. 
roku 410. Można w nich wyróżnić na pewno dwie zasadnicze linie przekazu pochodzące od Prospera Tiro i Priskosa z Panion, ale i one nie różnią się znacznie, jeżeli chodzi o opis przyczyn politycznych i przebiegu wyprawy Gejzeryka na Rzym. Przyczyny tego wydarzenia ujęte w porządek chronologiczny przedstawiają się następująco: zamordowanie Aecjusza, spisek Petroniusza Maksimusa, zamach na cesarza Walentyniana III i uzurpacja Maksimusa. Także opis samego ataku jest na ogół podobny: szybka mobilizacja floty królewskiej, desant w Italii, podejście pod Miasto, bezradność i próba ucieczki Petroniusza Maksimusa oraz jego śmierć z rąk rozjuszonych poddanych, wkroczenie Wandalów do Rzymu i długotrwała, gruntowna grabież Miasta, po której nastapił wywóz łupów i tłumów jeńców, wśród nich cesarzowej wdowy i jej córek. W każdej z tych dwóch relacji występuje też oryginalny wątek, którego nie ma w drugiej: w ,linii Prospera” jest to bohaterskie wstawiennictwo papieża Leona I Wielkiego, a w „linii Priskosa” motyw wezwania Gejzeryka na pomoc przez cesarzową wdowę Licynię Eudoksję, który, choć Priskos i Jan z Antiochii starali się osłabić wagę tej wiadomości za pomocą zwrotu oi $\delta$ ć $\varphi \propto \sigma \mathrm{l}, \mathrm{u}$ kolejnych autorów zdobywa pełną wiarygodność. Poza tym różnice pomiędzy poszczególnymi relacjami są niewielkie i dotyczą szczegółów, takich jak podanie lub niepodanie imion zabójców Walentyniana III, czy sprawców śmierci Petroniusza Maksimusa. Znamienne i szczególnie odbiegające od relacji o roku 410 jest całkowite pominięcie wątków i motywów religijnych. Najazd Gejzeryka jest przedstawiany jako fakt uwarunkowany konkretnymi wydarzeniami politycznymi i działaniami konkretnych ludzi. Nawet historyk Kościoła Ewagriusz ani słowem nie wspomina o próbie, czy karze Bożej i pozostaje na twardym gruncie faktów. Nie brak oczywiście dygresji (Prokopiuszowa opowieść o zgwałceniu żony Petroniusza Maksimusa przez Walentyniana III, czy Ewagriuszowe dywagacje nad charakterem kobiet), ale to tylko ciekawe ubarwienie bardzo rzeczowej relacji, wspólnej dla niemal wszystkich autorów. Historycy wschodniorzymscy wykazują nie tylko znajomość faktów, ale i znaczne nimi zainteresowanie. Łatwo to zrozumieć. Gra polityczna prowadzona przez Gejzeryka od 439 r., w przeciwieństwie do działań Alaryka nie była wyłącznym problemem Rzymian hesperyjskich, lecz równie boleśnie dotykała szczęśliwych poddanych cesarzy konstantynopolitańskich. Wydarzenia 455 r. były częścią większej całości dziejowego nurtu, który zawierał: korsarskie rajdy floty wandalskiej, bezkompromisową rozgrywkę militarną i polityczną między słabnącym cesarstwem zachodnim a Gejzerykiem, tajemnicze kontakty Gejzeryka z Flawiuszem Ardaburiuszem Asparem (ok. 400-471), rywalizację o wpływy między królem Wandalów a Rycymerem ${ }^{114}$, nieszczęsną wyprawę floty cesarza Leona I (ok. 401 - 18 I 474, cesarz od 457), rokowania pokojowe Gejzeryka z cesarzem Zenonem (425/431 - 9 IV 491, cesarz od 9 II 474) oraz chwalebną rekonkwistę Belizariusza (ok. 505 - III 565). Wszystko to było integralną częścią dziejów tak zachodnio- jak i wschodniorzymskich,

\footnotetext{
${ }^{114}$ Por. Anders, Flavius Ricimer, s. 453-466.
} 
a więc nie było na Wschodzie traktowane jako wydarzenia dziejące się far far away, tylko jako integralny element własnej historii, do której należał również pobyt Gejzeryka w Rzymie i konsekwencje tego wydarzenia. Stąd konkretne zainteresowanie i stosunkowo duża dokładność. Podkreślane są również we wszystkich relacjach dwa brzemienne w skutki fakty. Pierwszy to uprowadzenie ogromnej liczby jeńców, wśród nich kobiet domu cesarskiego, drugi to bezprecedensowe ogołocenie Rzymu z kruszcu, dzieł sztuki i wszelkich wartościowych rzeczy ${ }^{115}$. O tragicznym położeniu jeńców, szczególnie tych, którzy nie przedstawiali dużej wartości rynkowej, pisał Wiktor z Wity $(†$ po $510)^{116}$. Los jeńców, przede wszystkim porwanych z Rzymu, ale i uprowadzonych w rajdach pirackich czy pojmanych w bitwie $468 \mathrm{r}$., był przedmiotem troski dyplomacji wschodniorzymskiej. Patrycjusz Sewerus (konsul 474, daty urodzin i śmierci nieznane) posłujący do Kartaginy w imieniu cesarza Zenona zdołał uzyskać uwolnienie jeńców, będących w posiadaniu Gejzeryka i jego rodziny, ale nie tych, których zatrzymali królewscy wojownicy ${ }^{117}$. Dyplomacja konstantynopolitańska wyjednała też u Gejzeryka i Huneryka możliwość wyjazdu na Wschód Licynii Eudoksji i Placydii, a w okresie późniejszym Eudocji. Na tym polu były więc pewne sukcesy, ale drugi aspekt - straty materialne - był znacznie dotkliwszy. Gdy w 456 r. cesarz Awitus (ok. 385 - 17/18 X 456, cesarz od 9/10 VII 455) wkroczył do Rzymu, z najwyższym trudem opłacił osłaniające go oddziały wizygockie, wykorzystując resztki brązu zachowane w Mieście (przetapiając brązowe posagi, które nie interesowały Gejzeryka), a o sfinansowaniu wyprawy odwetowej przeciw Wandalom nie mógł nawet myśleć. Jego następcy mogli podejmować takie próby jedynie przy silnym wsparciu Wschodu. Grabież Rzymu w 455 r., połączona z utratą wpływów podatkowych z całości prowincji afrykańskich, zadała państwu straty finansowe nie do odrobienia ${ }^{118}$. Autorzy relacjonujący wydarzenia 455 r. zdawali sobie w jakimś stopniu sprawę, że mają do czynienia nie z jednorazowym nieszczęściem, spowodowanym przez władcę wędrownego plemienia szukającego swego miejsca w strukturach Imperium, jakim był Alaryk, lecz z elementem groźnych dla cesarstwa działań, prowadzonych przez władzę władcy stabilnego i silnego królestwa, który dzięki zdobyciu i splądrowaniu Miasta praktycznie utorował sobie drogę do pełnej suwerenności, potwierdzonej w 20 lat później formalnymi układami. Większość autorów (poza Prosperem i Pri-

${ }^{115}$ Por. Victor Vitensis, Historia persecutionis I 8 (24), ed. K. Vössing: Viktor von Vita, Kirchenkampf und Verfolgung unter den Vandalen in Africa, Texte zur Forschung 98, Darmstadt 2011, 46 „Quinto decimo regni sui anno Geisericus caperet Romam; et simul exinde regum multorum divitias cum populis captivavit".

${ }^{116}$ Por. tamże I 8 (25), ed. Vössing, s. 46.

${ }^{117}$ Por. Malchus, Fragmenta 5 (11-25), ed. R.C. Blockley, w: The Fragmentary Classicising Historians of the Later Roman Empire, s. 410.

118 Por. Castritius, Die Vandalen. Etappen einer Spurensuche, s. 105-107; Vössing, Das Königreich der Vandalen, s. 57-59; Modéran, Les vandales et l'Empire Romain, s. 187-189; Wilczyński, Gejzeryk i „czwarta wojna punicka”, s. 154-155; Hughes, Gaiseric, s. 142. 
skosem) znała dalszy rozwój wypadków i miejsce królestwa Wandalów na arenie politycznej, co jeszcze bardziej wzmagało ich zainteresowanie możliwie wiernym oddaniem toku wydarzeń.

\author{
ROMA CAPTA! \\ - COMMENTS ON ACCOUNTS ABOUT THE SACKS OF ROME \\ IN THE YEARS OF 410 AND 455 \\ IN THE WORKS OF SELECTED LATE ANTIQUE AUTHORS
}

\begin{abstract}
(Summary)
In the presented article the author analyses depictions of sieges and captures of Rome in the years 408-410 and 455 passed on by selected authors of Latin and Greek sources from the late antique. The scope of the research included sources containing more extensive narratives, while sources containing only laconic annual information solely about the fact of capturing the city were rejected. In the depictions of the capture of Rome by Alaric in 410 the authors rather tend to seek supernatural reasons, and less often logical explanations of the origin of the events, contrary to the depictions of the year 455 , where one can find almost exclusively rational justifications for the course of events, determined by political situation. While discussing the events of the year 410 the authors oftentimes create their own original digressions and allow for deviations from the historic reality. The relations about the year 455 are consistent and show only minor differences. Contrary to later opinions, the capture of Rome in 410 was not considered a gigantic tragedy outside Italy, although it was recognized as a breakthrough moment. For the eastern historians these events are remote, taking place in lands far from Constantinople and often their depiction is used to indicate the superiority of the Eastern Empire over the Western Empire. Sacco di Roma by Genseric in 455 , which is referred more precisely and recognized as an element of significant history and politics of the East (Vandals corsair raids, Leo the Thracian's expedition, recapturing Africa during the reign of Justinian I), is treated in an entirely different manner.
\end{abstract}

Key words: late antiquity, Alaric, Gaiseric, reports on the conquest of Rome.

Słowa kluczowe: późny antyk, Alaryk, Gejzeryk, relacje o zdobyciu Rzymu.

\title{
BIBLIOGRAFIA
}

\section{Źródła}

Augustinus, De civitate Dei, rec. E. Hoffmann, vol. 1: Libri I-XIII, CSEL 40/1, Pragae Vindobonae - Lipsiae 1899.

Augustinus, De excidio urbis Romae (De Urbis excidio sermo), PL 40, 715-723, thum.

K. Obrycki: Augustyn, Kazanie: O zniszczeniu miasta Rzymu, WST 12 (1999) 157-170. 
Augustinus, Epistolae 99 i 111, PL 33, 364-365 i 422-427.

Evagriuse Scholasticus, Historia Ecclesiastica, I-III, éd. J. Bidez - L. Parmentier, introduction G. Sabbah, traduction A.J. Ferstugière - B. Grillet - G. Sabbah, SCh 542, Paris 2011.

Gregorius Turonensis, Historiae, ed. B. Krusch - W. Levison, MGH Scriptores Rerum Merovingicarum I/1, 2. Aufl., Hannoverae 1951.

IoANNEs ANTIOCHENUs, Fragmenta quae supersunt omnia, recensuit anglice vertit indicibus instruxit S. Mariev, Berolini 2008.

Jordanes, De origine actibusque Getarum (= Getica), ed. Th. Mommsen, MGH Auctores Antiquissimi V/1, Berolini 1882, 53-138, thum. E. Zwolski: Kasjodor i Jordanes. Historia gocka czyli scytyjska Europa, Rozprawy Wydziału Historyczno-Teologicznego 49, Lublin 1984.

Jordanes, De summa temporum vel origine actibusque gentis Romanorum (= Romana), ed. Th. Mommsen, MGH Auctores Antiquissimi V/1, Berolini 1882, 1-52.

Ioannes Malalas, Chronographia, rec. L. Dindorfius, CSHB [11], Bonnae 1831.

Malchus, Fragmenta, w: The Fragmentary Classicising Historians of the Later Roman Empire. Eunapius, Olympiodorus, Priscus and Malchus, vol. 2: Text, Translation and Historiographical Notes, ARCA Classical and Medieval Texts, Papers and Monographs 10, Liverpool 1983, 402-455.

Orosius, Historiae adversvm paganos, rec. C. Zangemeister, CSEL 5, Vindobonae 1882, 1-564.

Paulus Diaconus, Historia Romana, w: Eutropi Breviarium ab urbe condita cum versionibus Graecis et Pauli Landolfique additamentis, rec. et adnot. H. Droysen, MGH Auctores Antiquissimi II, Berolini 1879, 4-224, tłum. I. Lewandowski: Paweł Diakon, Historia rzymska, w: Paweł Diakon, Historia rzymska. Historia Longobardów, Warszawa 1995, 1-196.

Philostorgius, Historia Ecclesiastica, hrsg. von J. Bidez - F. Winkelmann, GCS 21, Berlin 1972, 1-150.

Priscus, Fragmenta, ed. R.C. Blockley, w: The Fragmentary Classicising Historians of the Later Roman Empire. Eunapius, Olympiodorus, Priscus and Malchus, vol. 2: Text, Translation and Historiographical Notes, ARCA Classical and Medieval Texts, Papers and Monographs 10, Liverpool 1983, 222-377.

Procopius Caesariensis, De bellis libri I-IV, rec. J. Havry, addenda et corrigenda adiecit G. Wirth, w: Procopius Caesariensis, Opera omnia, vol. 1, Lipsiae 1962.

Prosperus Tiro Aquitanus, Chronicon, ediert, übersetzt und kommentiert von M. Becker - J.-M. Kötter: Chronik. Laterculus regum Vandalorum et Alanorum, Kleine und fragmentarische Historiker der Spätantike. G 5-6, Paderborn 2016 [Chronik, 64-141; Laterculus regum Vandalorum et Alanorum, 354-361].

Socrates, Historia Ecclesiastica, hrsg. von G.Ch. Hansen, mit Beiträgen von M. Sirinjan, GCS NF 1, Berlin 1995, tłum. S.J. Kazikowski: Sokrates Scholastyk, Historia Kościoła, Warszawa 1972.

Sozomenus, Historia Ecclesiastica, hrsg. von J. Bidez - G.Ch. Hansen, GCS NF 4, 2. Aufl., Berlin 1995.

Victor Vitensis, Historia persecutionis, hrsg., eingel. und übers. von K. Vössing: Viktor von Vita: Kirchenkampf und Verfolgung unter den Vandalen in Africa, Texte zur Forschung 98, Darmstadt 2011.

Zosimos, Historia Nova, ed. L. Mendelssohn, Lipsiae 1887. 


\section{Opracowania}

Anders F., Flavius Ricimer. Macht und Ohmacht des weströmischen Heermeisters in der zweiten Hälfte des 5 Jahrhunderts, Frankfurt am Main 2010.

Castritius H., Die Vandalen. Etappen einer Spurensuche, Stuttgart 2007.

Clover F.M., Geiseric the Statesman. A Study of Vandal Foregin Policy, Chicago 1966 (Dissertation).

Delaplace Ch. La fin de l'Empire romain d'Occident. Rome et les Wisigoths de 382 à 531, Rennes 2015.

Demandt A., Der Fall Roms. Die Auflösung des römischen Reiches im Urteil der Nachwelt, München 1984.

Demandt A., Die Spätantike. Das Römische Reich von Diocletian bis Justinian 284-565 n. Chr., 2. Aufl., München 2008.

Halsall G., Barbarian Migrations and the Roman West, Cambridge 2007.

Heather P., Upadek Cesarstwa Rzymskiego, tłum. J. Szczepański, Poznań 2006.

Henning D., Periclitans res publica. Kaisertum und Eliten in der Krise des Weströmischen Reiches 454/5-493 n. Chr., Historia Einzelschriften 133, Stuttgart 1999.

Hughes I., Stilicho. The Vandal Who Saved Rom, Barnsley 2010.

Hughes I., Patricians and Emperors. The Last Rulers of theWestern Roman Empire, Barnsley 2015.

Hughes I., Gaiseric. The Vandal Who Destroyed Rome, Barnsley 2017.

Janssen T., Das weströmische Reich vom Tode des Theodosius bis zur Ermordung Stilichos (395-408), Marburg 2004.

KAMPers G., Geschichte der Westgoten, Padeborn - München 2008.

Kulikowski M., Barbarians in Gaul, Usurpers in Britain, „Britania” 31 (2000) 325-345.

Kulikowski M., Wojny Rzymu z Gotami od III wieku do Alaryka., Oświęcim 2015.

McEvoy M.A., Child Emperor Rule in the Late Roman West AD 367-455, Oxford 2013.

Meier M. - Patzold. S., August 410 - ein Kampf um Rom, Stuttgart 2010.

Merrills A. - Miles R., The Vandals, Chichester 2010.

ModÉRAn Y., Les vandales et l'Empire Romain, Arles 2014.

SpychaŁa D., Cesarze rzymscy a arianizm od Konstantyna Wielkiego do Teodozjusza Wielkiego (312-395), Poznań 2007.

Stickler T., Aëtius. Gestaltungsspielräume eines Heermeisters im ausgehenden Weströmischen Reich, München 2002.

Steinacher R., Die Vandalen. Aufstieg und Fall eines Barbarenreichs, Stuttgart 2016.

Vössing K., Das Königreich der Vandalen. Geiserichs Herrschaft und das Imperium Romanum, Darmstadt 2014.

Wijnendaele J.W.P., Stilicho, Radagaissus, and the So-Called „Battie of Faesulae” (406 CE)., ,Journal of Late Antiquity” 9 (2016) nr 1, 267-284.

WiLCZyński M. Germanie w stużbie zachodniorzymskiej w Vw. n.e. Studium historyczno-prosopograficzne, Kraków 2001.

WiLCZYŃSKI M., Gejzeryk $i$,,czwarta wojna punicka”, Oświęcim 2016.

Wolfram H., Die Goten. Von den Anfängen bis zur Mitte des sechsten Jahrhunderts. Entwurf einer historischen Ethnographie, 3. Aufl., München - Wien 1990. 